\title{
New records and new species of Asclepiadaceae from Namibia
}

\author{
P.V.BRUYNS*
}

Keyиords: Asclepiadaceae, Namibia, new records, neu species, taxonomy

\section{ABSTRACT}

Eleven species of Asclepiadaceae not previously recorded from Namibia are discussed. Of these. Brachvstelma codonanthum Bruyns. B. recurvatum Bruyns and Schizoglossum saccatum Bruyns are new species. The new combinations Brachystelma gymnopodum (Schltr.) Bruyns (for Ceropegia pygmaea Schinz) and B. schulrzei (Schltr.) Bruyns (for Tenaris schultzei (Schltr.) E. Phillips] are proposed and the delimitation of Brachystelma $\mathrm{R}$. Br. against Ceropegia L. and Tenaris E. Mey. is discussed. Notes are also included on litle-known species, and the species of Gomphocarpus R. Br. in Namibia are enumerated.

\section{UITTREKSEL}

\begin{abstract}
Elf spesies van die Asclepiadaceac wat nog nie vorheen in Namibia aangeteken is nie, word hespreek. Hiervan is Brachystelma codonanthum Bruyns. B. recurvatum Bruyns en Schizoglossum saccatum Bruyns nuwe spesies. Die nuwe kombinasies Brachystelma gymmopodum (Schltr.) Bruyns (vir Ceropegia pygmaea Schinz) en B. schultzej (Schltr.) Bruyns | vir Tenaris schultzei (Schltr.) E. Phillips| word voorgestel en die omgrensing van Brachystelma R. Br. teenoor Ceropegia L. en Tenaris E. Mey. word bespreck. Notas oor min bekende spesies word ook ingesluit en die spesies van Gomphocarpus $\mathbf{R}$. Br. in Namibia word opgenom.
\end{abstract}

\section{INTRODUCTION}

Several collecting trips to Namibia since 1987 have brought to light species of Asclepiadaceae not previously recorded from Namibia. Searches through the material preserved in the National Herbarium. Windhoek (WIND) have also revealed a feu already recorded but not dealt with in Huber (1967).

The recently published list of Namibian plants ( Kolberg et (al. 1992) has various errors in the account of the Asclepiadaceae. Some of these are rectified here. Keys are provided to the taxa where possible. The very confused state of the taxonomy of the complex of genera around Asclepias does not allow for an exact statement as to the generic placing of all the species. This problem is being addressed by Nicholas (pers. comm. 1994) and once this has been sorted out it should be possible to construct keys to these genera. The genera are arranged alphabetically except for those in the Schioglossum complex which are all discussed together.

\section{ASCLEPIAS $L$.}

Apart from the larger. shrubby species of Asclepias. which are here placed under Gomphocarpus, no others are listed by Huber (1967). However. at least two collections of small. herbaceous species are known from $\mathrm{Na}$ mibia. Their identification poses somewhat of a problem as generally species of the narrow-leaved. herbaceous type in Asclepias, as with Pachicarpus E. Mey.. are known from the eastern side of southem Africa only (Nicholas

\footnotetext{
* Bolus Herbarium. University of Cape Toun. Private Bayg. Rondebosch $77(x)$

MS. received: $1994 \cdot 12-(1) 2$
}

1982: 450). Since the genus Asclepias is now intended to be restricted to the American species (see discussion under Gomphocarpus), these will all be moved to other genera in due course.

Key to the herbaceous species of Asclepias for Namibia

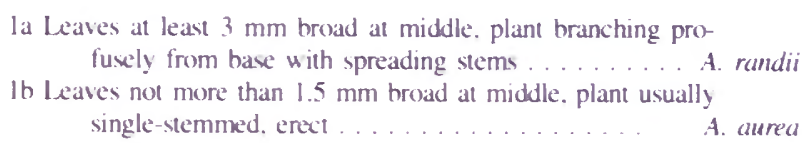

1.1 Asclepias aurea (Schltr.) Schltr.

A. caurea is widespread along the eastern side of southem Africa and also occurs in Zimbabwe (Brown 190219(4). According to Nicholas (1982: 452), it does not occur in the Cape Province but I have seen plants undoubtedly belonging to this species south of Kuruman in the northern Cape (Bruins 5836. BOL).

There is a small specimen in WIND which is probably also referable to $\mathrm{A}$. aurea. However. whereas material from Kuruman fits the description of $A$. aurea exactly, in this Namibian collection there are some differences. It is slightly more hairy than A. aurea (where the leaves are glabrous except sometimes for a few hairs on the midrib beneath) and the peduncles are also much shorter. A brief description of this material follows.

Plant 100-250 mm tall. stems just over I mm thick. erect. with fine hairs in a single line. internodes 15-20 $\mathrm{mm}$ long. Leaves up to $70.0 \times 1.1 \mathrm{~mm}$. santily hairy on both sides. \pm sessile. Peduncle up to $20 \mathrm{~mm}$ long. tinely hairy in a single line. bearing 4 flowers. Pedicel 10-12 mm long. very scantily hairy. Comolla about $8 \mathrm{~mm}$ diam.. lobes with few hairs on dorsal surface. Corma lobes about 


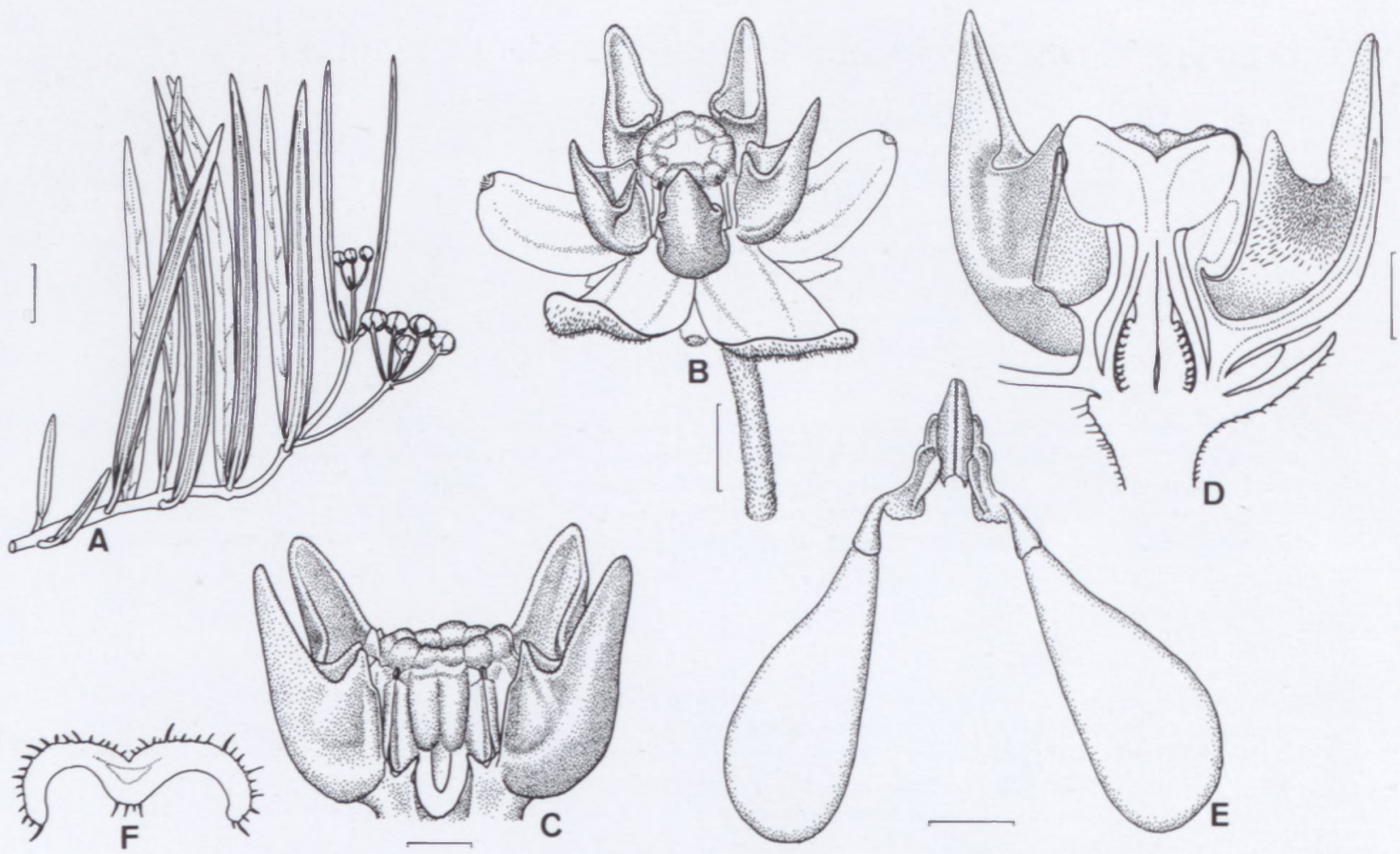

FIGURE 1.-Asclepias randii, Bruyns 5487. A, portion of plant; B, flower; C, gynostegium with one corona lobe removed; D, half flower, papillae on inner face of corona lobes clearly visible; E, pollinarium; F, cross-section of leaf, taken near middle. Scale bars: A, $10 \mathrm{~mm}$; B, 2 mm; C, F, $1 \mathrm{~mm}$; D, $1 \mathrm{~mm}$; E, $0.25 \mathrm{~mm}$.

$2.5 \mathrm{~mm}$ long, with many papillae inside hood. Otherwise as in A. aurea.

\section{Specimen examined}

NAMIBIA.-2217 (Windhoek): near Windhoek, (-CA), Seydel 4109 coll. Jan. 1965 (WIND).

\subsection{Asclepias randii S. Moore. Figure 1.}

Small herbs belonging probably to this species were observed among short grasses on a gentle slope in the Otavi Mountains. According to Brown (1902-1904: 351), $A$. randii is known only from central Zimbabwe. However, the species is very similar to A. modesta N.E. Br. (Nicholas pers. comm. 1994) which is known to be widespread in south tropical Africa with known localities in Tanzania, Zambia, Malawi and Angola (Brown 1902-1904). The two seem to be separated mainly by the rather long, erect apices of the corona lobes in $A$. randii, which project somewhat above the gynostegium.

A. modesta was made a synonym of Trachycalymma pulchellum (Decne.) Bullock (1953: 351), a genus which Bullock defined mainly by the papillae or 'papilliform hairs' on the inner face of the hood formed by the corona. These papillae are present in both the material illustrated here of $A$. randii (Figure 1D) and A. aurea but neither appears to have been referred to Trachycalymma Bullock.

\section{Specimen examined}

NAMIBLA.-1917 (Tsumeb): Otavi Mountains, (-DB), Bruyns 5487 (BOL; K, alcohol only).

\section{BRACHYSTELMA Sims}

Two new species of Brachystelma are described. The generic boundaries of Brachystelma against Ceropegia and Tenaris E. Mey. are discussed and this results in two new combinations in Brachystelma. A key to these genera and Macropetalum Burch. is given and also one to all the species of Brachystelma in Namibia.

2.1 Brachystelma recurvatum Bruyns sp. nov., a ceteris speciebus lobis corollae pedicellisque longissimis angustissimis differt. Typus: Namibia, 1917 (Tsumeb): Otavi Mountains, (-DB), 5-2-1993, Bruyns 5486 (BOL, holo.; WIND, K, iso.). Figures 2, 3.

Plant with flattened subglobose tuber up to $80 \mathrm{~mm}$ diam., with 1-several erect simple to branched stems reaching 60-300 mm tall. Stems 1-2 mm thick, pubescent,

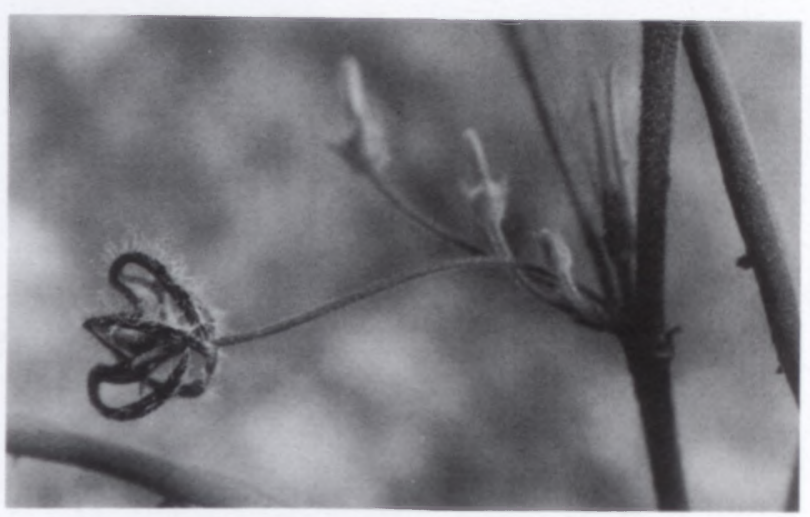

FIGURE 2.-Brachystelma recurvatum, Bruyns 5486, showing very slender pedicels and recurved petals. 


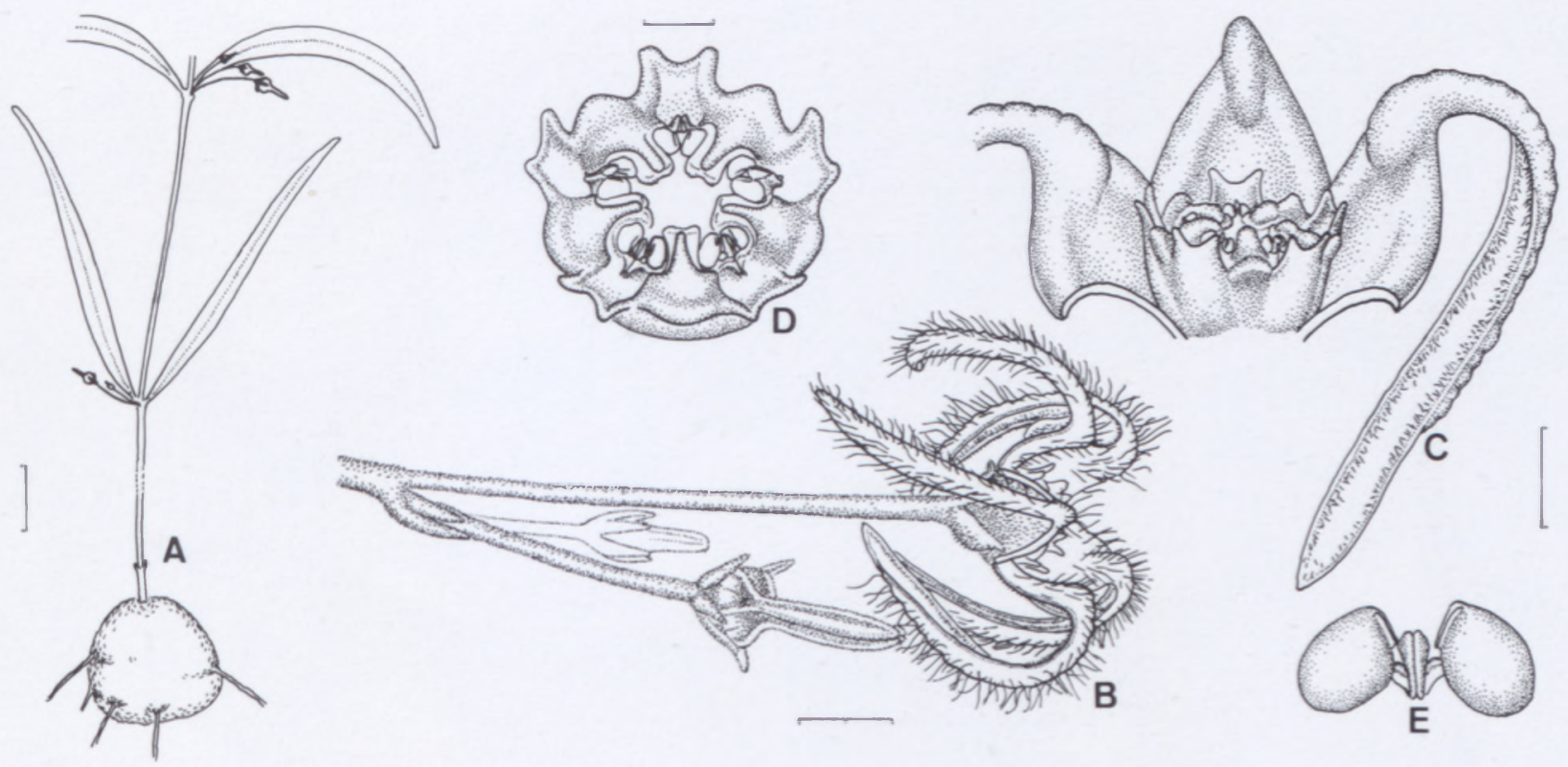

FIGURE 3.-Brachystelma recurvatum, Bruyns 5486. A, plant, much reduced in length (up to 300 mm tall); B, flower and bud; C, dissected flower; D, gynostegium; E, pollinarium. Scale bars: A, $10 \mathrm{~mm} ; \mathrm{B}, 2 \mathrm{~mm} ; \mathrm{C}, 1 \mathrm{~mm} ; \mathrm{D}, 0.5 \mathrm{~mm} ; \mathrm{E}, 0.25 \mathrm{~mm}$ (at B).

green to purplish. Leaves $30-90 \times 3-13 \mathrm{~mm}$, narrowly lanceolate, margins recurved, pubescent on both surfaces, green, petiole $1.0-1.5 \mathrm{~mm}$ long. Inflorescence extra-axillary, bearing 1-4 successively developing flowers, pubescent; peduncle 0-2 $\times 0.5 \mathrm{~mm}$; pedicels $10-16 \times 0.25 \mathrm{~mm}$, purplish. Corolla 7-8 mm diam., outside green finely pubescent, inside with fine crinkled white hairs, with very shallow tube $( \pm 0.5 \mathrm{~mm}$ deep) enclosing base of gynostegium; lobes within greenish black blotched with very pale yellow (nearly colourless), with \pm deltoid basal portion about $1.5 \mathrm{~mm}$ broad at base then abruptly narrowing into recurved tail $\pm 6 \times 0.5 \mathrm{~mm}$ (seen in bud as long beak), margins recurved. Gynostegium $\pm 1.5 \mathrm{~mm}$ diam., glabrous; outer corona lobes truncate-bifid, pale yellow with large greenish black patch on inner surface; inner lobes with dorsal projection confluent with outer lobes and narrow limb incumbent on anthers nearly equalling them, with droplets of colourless fluid secreted on backs, practically colourless (pale yellow).

Brachystelma recurvatum is unlike any other species known in Namibia, with exceptionally slender pedicels and corolla lobes. The corolla lobes are strongly recurved behind the corolla with the narrow tail then sometimes bent back and partly obscuring the gynostegium, hence the epithet recurvatum. The corona structure is typical of the genus with short, truncate-bifid outer corona lobes and very small inner lobes. Plants were found among short grasses on a gentle slope between dolomite outcrops growing in reddish loam. This is the 'Tenaris spec. indet.' mentioned and illustrated rather poorly in Bruyns (1984) from a specimen collected west of Outjo (no material preserved). Since there seems to be some vagueness about the distinctions between Tenaris and Brachystelma, this is discussed separately under 2.4 and 2.5 .

2.2 Brachystelma codonanthum Bruyns sp. nov., a $B$. dinteri Schltr. cognatum sed flore campanulato coronaque exteriore cupulata, a B. cupulato R.A. Dyer lobis corollae deltoideis et corona exteriore quinqueloba discedit. Typus: Namibia, 1918 (Grootfontein): northeast of Grootfontein, (-BB), Bruyns 5518 (BOL). Figure 4.

Plant arising from a depressed-globose tuber up to 20 $\times 30 \mathrm{~mm}$. Stem usually solitary, simple, \pm erect, $20-150$ $\times \pm 1.5 \mathrm{~mm}$. Leaves $11-22 \times 9-15 \mathrm{~mm}$, elliptic, tapering into petiole 1-2 mm long. Flowers in small sessile groups extra-axillary at nodes, opening successively. Pedicel spreading, $2-3 \times 0.5 \mathrm{~mm}$. Sepals lanceolate, acute, $2 \times$ $0.5 \mathrm{~mm}$. Corolla $5 \times 9-10 \mathrm{~mm}$, outside pale green to brown, inside glabrous obscurely transversely rugose green to brown with greenish tips, campanulate; tube \pm $2.5 \times 4.0 \mathrm{~mm}$ (across mouth), broadly conical; lobes $3-4$ $\times 3 \mathrm{~mm}$, deltoid, spreading. Gynostegium $1.5 \times$ nearly 3.0 $\mathrm{mm}$, dark brown, glabrous, cupular; outer conona lobes rising above rim of cup, bifid, narrowing towards apex; inner lobes cushion-like, arising lower down in cup and adpressed to backs of anthers near their base, very short and usually leaving most of anthers uncovered.

\section{Specimens examined}

NAMIBIA.-1819 (Karakuwisa): (-CC), Bruyns 5990 (BOL).1918 (Grootfontein): (-BB), Bruyns 5518 (BOL).

With its solitary, erect stem and elliptical leaves, this species resembles $B$. dinteri vegetatively and, when collected, was assumed to be that species. On flowering, it turned out to have a completely different, campanulate flower with somewhat cupular corona. In B. dinteri the outer corona lobes arise between the broad dorsal parts of the inner lobes which determine the pentagonal shape of the corona. In $B$. codonanthum the inner corona lobes arise on the inside of the cupular outer corona as in $\boldsymbol{B}$. cupulatum. From B. cupulatum it is distinguished by differently-shaped corolla lobes with rugose surface (oblong in B. cupulatum, deltoid in B. codonanthum) and the outer corona cup which is deeply 5 -lobed in $B$. codonanthum and notched around the apex in B. cupulatum. B. codonan- 

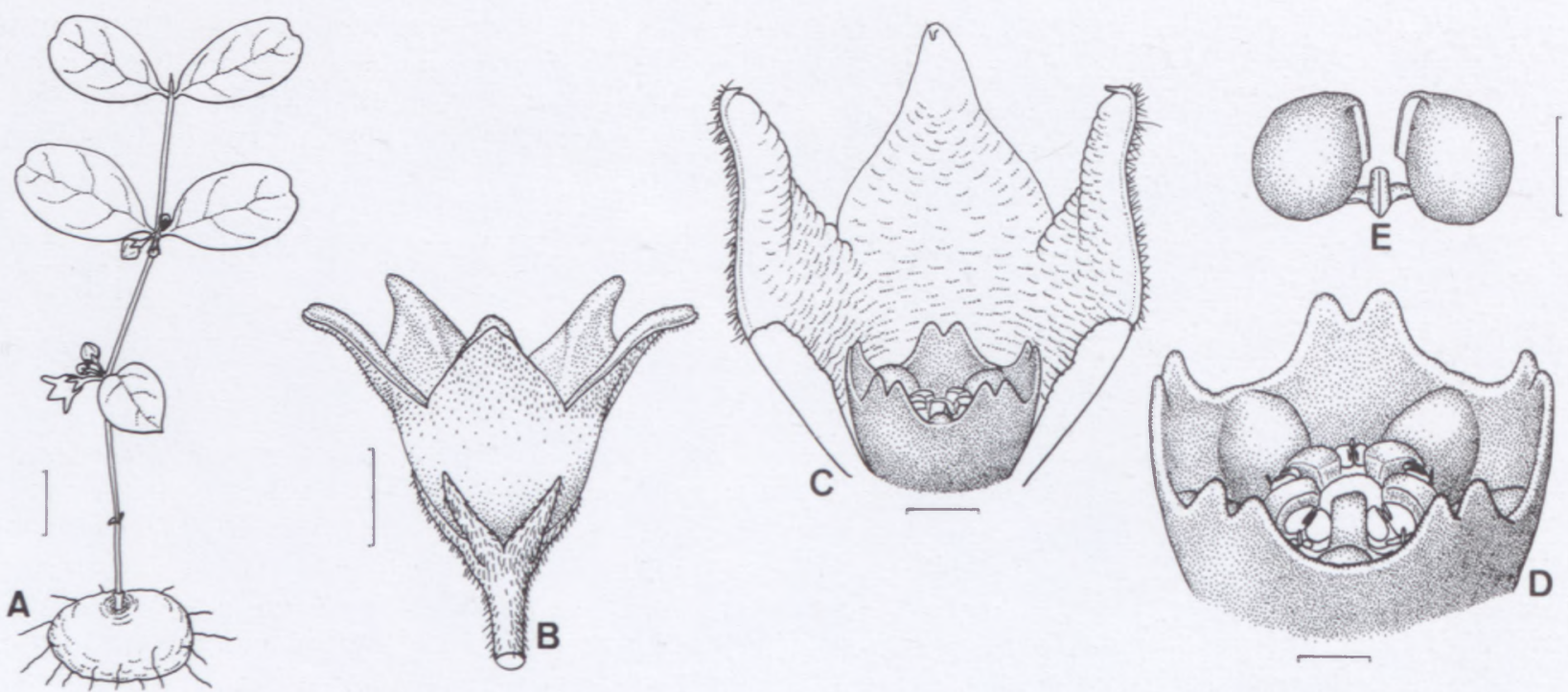

FIGURE 4.-Brachystelma codonanthum, Bruyns 55/8. A, portion of plant; B, flower; C, dissected flower; D, gynostegium; L, pollinarium. Scalc bars: A, $10 \mathrm{~mm}$; B, $2 \mathrm{~mm}$; C, $1 \mathrm{~mm}$; D, $0.5 \mathrm{~mm}$; E, $0.25 \mathrm{~mm}$.

thum was found in two places northeast of Grootfontein growing in deep white sand in open forest.

\subsection{Brachystelma blepharanthera (Schltr.) H.E. Huber}

This small species of Brachystelma was not dealt with in Bruyns (1984) but, alongside that account, Müller (1984) recorded its 'rediscovery' in 1983 after 70 years since Dinter's original collections in 1909 and 1910. Actually it had been collected long before this in 1968 by C. Grabow near Gobabis, but this and another collection by Woortman from north of Okahandja remained unidentified at WIND until recently.

More intensive collecting over southern Namibia has revealed that this species is widely distributed in the southern half of the country from Gobabis and Okahandjai southwards to Helmeringhausen. In the southern parts it is the only known species of Brachystelma (Figure 5).

Unlike other species, B. blepharanthera grows in arid places on pebbly or stony ground usually in the open or among short bushes (sometimes even among Rhigozum! trichotomum). From Gobabis to Windhoek and southwards to Nauchas it was mainly seen in spots with it scanty cover of small bushes with the ground densely strewn with quartz and other small pebbles. Several time, it was observed growing with Lithops pseudotruncatella. Around Helmeringhausen it was usually found on stony. north-facing mountain slopes.

The tuber of $B$. blepharanthera is usually cylindrical to irregularly top-shaped (Figure 6A) or very occasionally flattened discoid. The largest seen was $\pm 80 \times 50 \mathrm{~mm}$ and several up to $80 \mathrm{~mm}$ long and only $20-30 \mathrm{~mm}$ thick werc found. This shape is unique in Brachystelma. It is often tightly wedged among stones and can be difficult to extract. In the northern part of the distribution, plants seen were rarely more than $50 \mathrm{~mm}$ tall above the soil with the branches spreading horizontally up to about $100 \mathrm{~mm}$. Further south, the plant may be erect with stems up to 300 $\mathrm{mm}$ tall. The cylindrical stems are almost always finely mottled with purple and the small leaves are usually crinkled (as in the largest plant in Figure 6A).

Generally in this species the sepals are green to brownish, the corolla tube is white (sometimes lightly suffused with pink), the lobes are green (sometimes with purplish margin), the inner corona lobes are green whereas the rest of the gynostegium is white. In the northern part of the range the corolla lobes vary from $2-4 \mathrm{~mm}$ long,

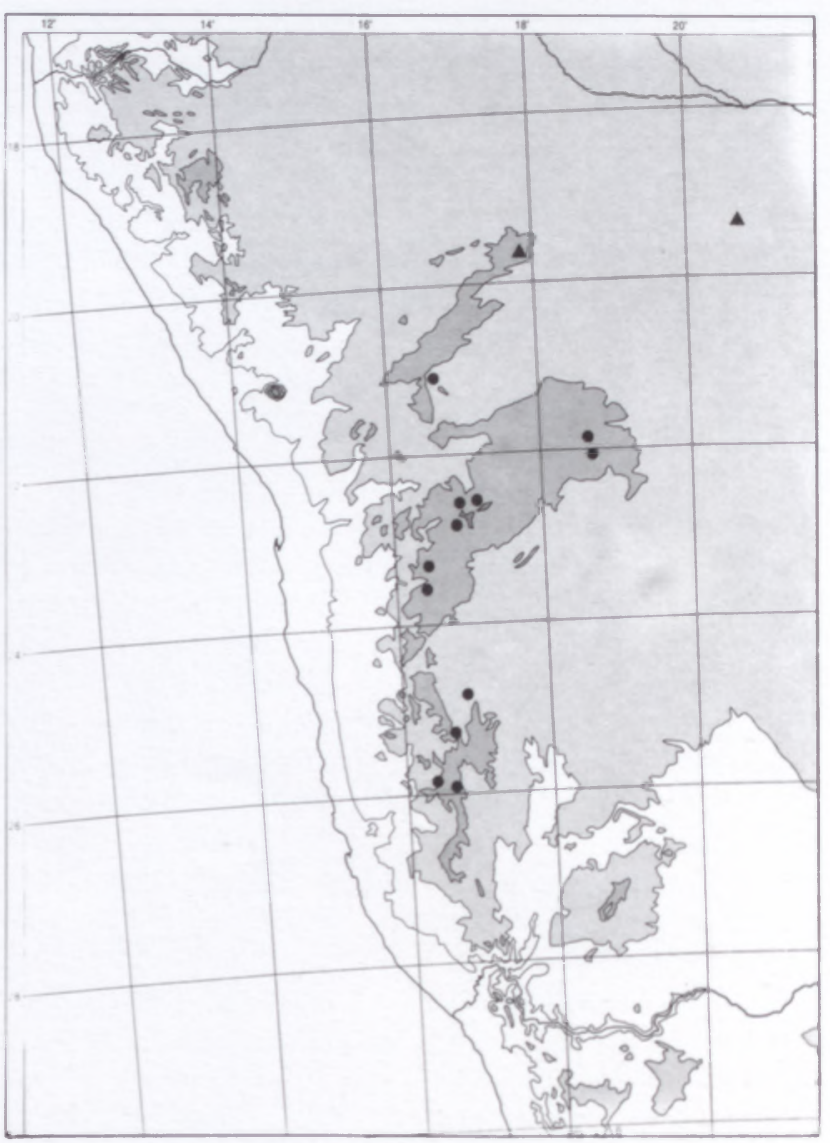

FIGURL: 5.-Disubution of Brachsselma blepharanthera. and Pachycarpus schweinfurthii, $\mathbf{A}$, in Namibia. 


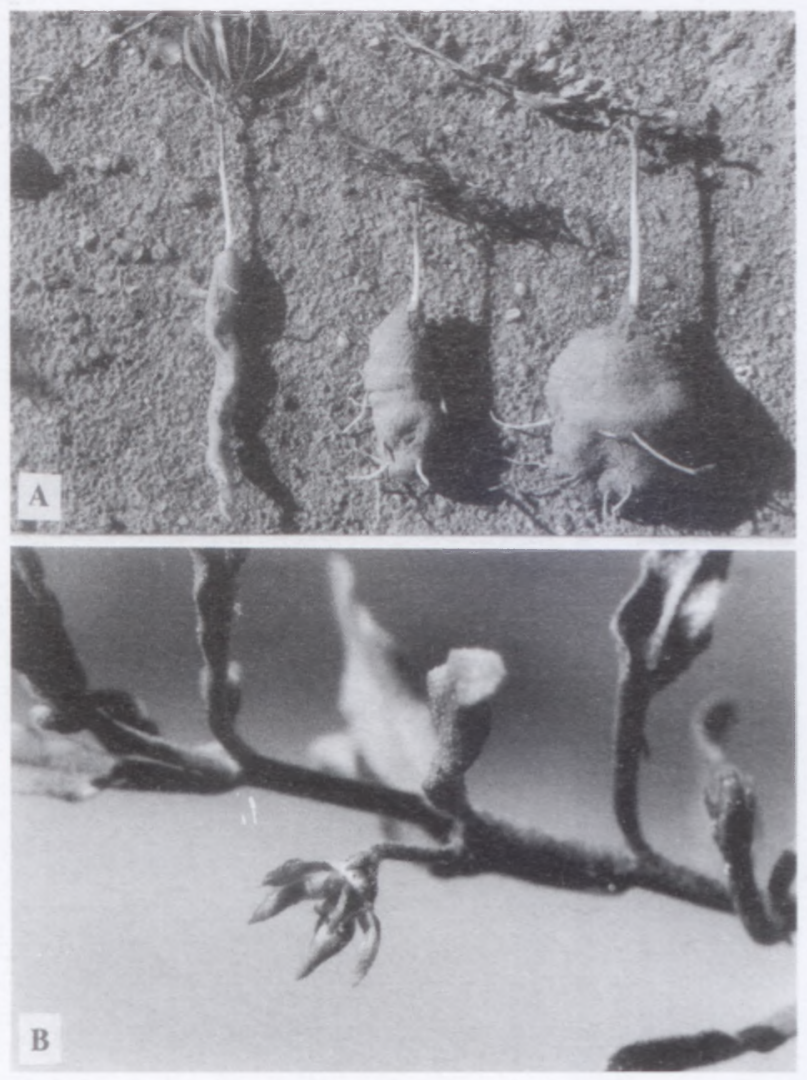
plants excavated to show peculiar elongated tubers, usually crinkled leaves clearly visible in plant with largest tuber; B, plant with
FIGURE 6.-A, B, Brachystelma blepharanthera, Bruyns 5818: A, three

ster 1989). None of these accounts deals with the problem of the boundaries between the two genera which is not as insignificant as this neglect may imply. Dyer (1980) followed Brown (1907-1909) in separating the two genera as follows:

la Corolla tubular with the tube usually 2 to several times as long as its diameter at middle ........... Ceropegia lb Corolla opening nearly flat or tube campanulate, when tubular then less than twice as long as its diameter at middle

Brachystelmo

Many genera within the Stapelieae exhibit variation in the corolla from nearly rotate through campanulate to tubular (cf. Stapelia leendertziae N.E. Br., Tridentea choanantha (Lavranos \& Hall) L.C. Leach, Echidnopsis mijerteina Lavranos as extreme examples within their respective genera) and it is therefore not surprising to find this variation in Brachystelma. However, the tubular-flowered species of Brachystelma (such as B. oianthum Schltr.) may begin to resemble Ceropegia as it is defined above. Similarly some species may have been placed in Ceropegia because of this single character while their closest relatives are in Brachystelma.

The generic position of Ceropegia pygmaea is of concern here. It is clear from Brown (1902-1904), Huber (1957) and Dyer (1980) that C. pygmaea occupies an isolated position in Ceropegia, where its very long corolla tube places it according to the above definition.

In general the gynostegium of Ceropegia has a shallowly cupular outer corona with the usually bifid lobes only slightly overtopping the bases of the inner lobes. The dorsiventrally flattened inner lobes are incumbent on the backs of the anthers and then rise up, connivent, in a column above the centre of the style head. Whereas exactly this inner corona structure is found randomly in several genera, but is useful there only to separate species [cf. Lavrania cactiformis (Hook.) Bruyns and L. picta (N.E. Br.) Bruyns, (1993)], it is remarkably reliable in separating Ceropegia from its allies. As far as I am aware there are only three species out of about 160 where this is not found: $C$. pygmaea (southern Africa), C. loranthiflora $\mathrm{K}$. Schum. (Ethiopia: own unpublished drawings of material at $\mathrm{K}$ ) and $C$. dorjei C.E.C. Fisch. [Bhutan: illustrated in Huber (1957) but gynostegium possibly based on a juvenile flower].

NAMIBIA -2116 (Okahandja): (-BA), Woortman 221 (WIND). 2118 (Steinhausen): (-DC), Grabow 19 (WIND). 2216 (Otjimbingwe): (-DB), Van Vuuren s.n. (WIND); (-DD), Bruvns 5626 (K). 2217 (Windhoek): (-CA), Van Vuuren s.n. (WIND). 2218 (Gobabis): (-BA), Bruyns 5818 (WIND). 2316 (Nauchas): (-AD), Pehlemann I334 (WIND); (-CB), Bruyns 5639 (BOL). 2416 (Maltahöhe): (-DD), Bruvns 5658 (BOL). 2516 (Helmeringhausen): (-BC), Bruyns 5681 (BOL); (-CD). Bruyns 5703 (BOL); (-DC), Bruyns 5734 (BOL).

\section{Brachystelma gymnopodum, a new name for Ceropegia pygmaea Schinz}

The genera Brachystelma and Ceropegia have similar distributions around the perimeter of the Indian Ocean from southern Africa to Australia. The only recent regional treatments of both genera have covered southern Africa (Dyer 1980) and Australasia (Forster 1988; Bruyns \& For-
The gynostegium in Brachystelma on the other hand, has an extremely variable outer corona: from slender bifid lobes to a tube containing the whole gynostegium. The inner corona lobes are invariably small and often only just touch the backs of the anthers near their base. In a few cases they exceed them, rising up connivent in a column above the style head as in Ceropegia: B. blepharanthera, B. dyeri K. Balkwill, B. gracile E.A. Bruce, B. pachypodium R.A. Dyer and B. schizoglossoides (Schltr.) N.E. Br. are the only examples known to me. In all these the corolla tube is shorter than it is broad and so these species separate out (according to Dyer 1980) clearly as Brachystelma, where their closest relatives are as well. 
In Ceropegia pygmaea the outer corona forms a deep cup hiding the rest of the gynostegium (Figure 8G, H). The inner corona lobes are short, touching the backs of the anthers and do not exceed them (Figure 8K). As can be seen, the corolla is very variable in length, ranging from twice its maximum breadth with the mouth upturned (Figure 8B) to about five times its maximum breadth (Figures $8 \mathrm{C}$; 9) with the mouth turned down towards the soil and usually touching it or even becoming slightly buried among leaf litter and loose sand [exactly as observed in Echidnopsis ballyi (Marn.-Lap.) P.R.O. Bally, (Bruyns 1988)].

In $C$. pygmaea the leaves vary from broadly ovate to linear. Narrow-leaved forms are difficult to distinguish when sterile from Brachystelma stenophyllum (Schltr.) R.A. Dyer and, in fact, vegetatively these two are very similar: both are small plants arising from a flattened-globose tuber with short stems branched just above ground level, producing a cluster of leaves usually close to the ground with flowers developing on short, horizontal peduncles near the base of the stems. Their gynostegia are almost identical. A similar corona structure is also found in B. cupulatum and B. brevipedicellatum Turrill. These four species possibly form a group with corolla increasing in tubularity from the nearly rotate state in B. brevipedicellatum via B. stenophyllum (illustrated in Bruyns 1984) to the deep tube of $C$. pygmaea. Whereas $C$. pygmaea occupies an isolated position in Ceropegia, its close affinities to $B$. stenophyllum suggest that it would be much better accommodated in Brachystelma and it is therefore transferred to that genus. However, it cannot be called Brachystelma pygmaeum because of the earlier and validly published Brachystelma pygmaeum (Schltr.) N.E. Br. Therefore a new combination is required:
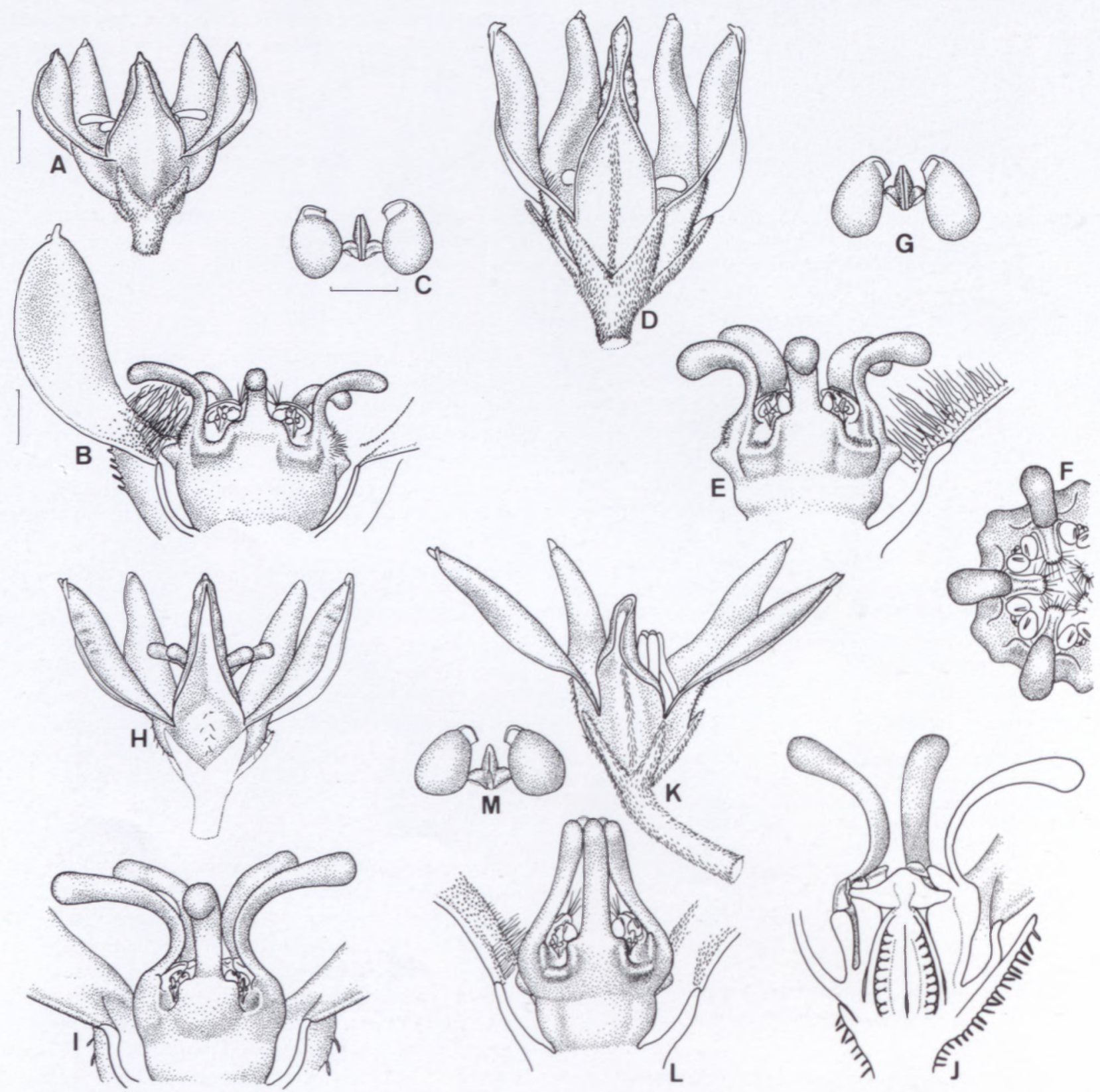

FIGURE 7.-Brachystelma blepharanthera. A, D, H, K, flowers; B, E, I, L, dissected flower showing gynostegium from side; F, face view of gynostegium; J, half flower; C, G, M, pollinaria. Scale bars: A, D, H, K, 1 mm (at A); B, E, F, I, J, L, 0.5 mm (at B); C, G, M, 0.25 mm (at C). A-C, Bruyns 5626; D-G, Bruyns 5639; H-J, Bruyns 5658; K-M, Bruyns 5703. 


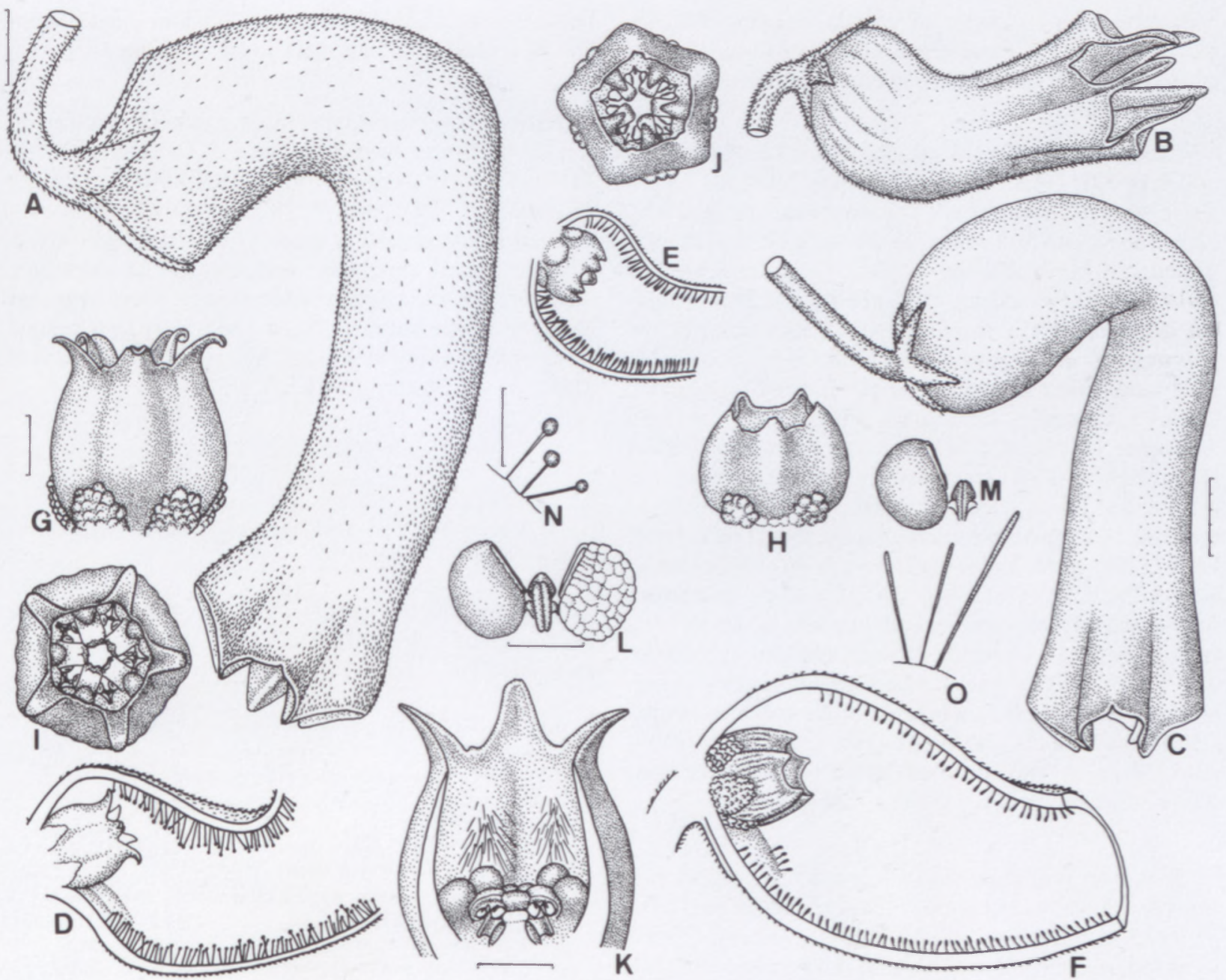

FIGURE 8.-Brachystelma gymnopodum (Ceropegia pygmaea). A-C, flowers; D-F, corolla dissected; G, H, side view of corona; I, J, face view of gynostegium; K, dissected gynostegium; L, M, pollinaria; N, O, hairs in corolla tube. Scale bars: A, B, D, E, F, 3 mm (at A); C, 5 mm; G, H, I, J, 1 mm (at G); K, 1 mm; L, M, 0.25 mm (at L); N, O, 0.5 mm (at N). Drawn from: A, D, G, I, K, L, N, Bruyns 2078, Gravelotte, eastern

2.4 Brachystelma gymnopodum (Schltr.) Bruyns, comb. nov. Ceropegia gymnopoda Schltr. in Bulletin de l'Herbier Boissier 4: 450 (1896). Type: Namibia, Rautanen $82(\mathrm{Z})$.

Ceropegia pygmaea Schinz (1888). Type: Namibia, Schinz 147 (Z). Figures 8, 9.

\section{Tenaris E. Mey. in Namibia? A new combination in Brachystelma for Tenaris schultzei (Schltr.) \\ E. Phillips}

Brown (1902-1904) listed three species of Tenaris from tropical Africa (two from Somalia and one from Tanzania) and commented that 'there is little beyond habit to distinguish this genus from Brachystelma'. In the key he used the 'terminal raceme or lax panicle' of flowers to distinguish these species from Brachystelma. Brown (1907-1909) listed four species of Tenaris for South Africa. In this account he used characters of the flower "corolla tube very short; lobes free, not reflexed' etc. to distinguish Tenaris from Brachystelma but it is not clear how this could succeed in separating these genera, for there are many species of Brachystelma to which this would apply equally well. It appears that $T$. chlorantha Schltr., where there is no 'terminal raceme or lax panicle', may be the reason for Brown's abandoning his earlier distinctions for Tenaris.

The seven species listed in Brown (1902-1909) appear to share the following characteristics:

Flowering stems slender, erect, unbranched, glabrous; leaves linear 1-2 mm broad or filiform, blade narrower than midrib on flowering stems, glabrous; peduncle and

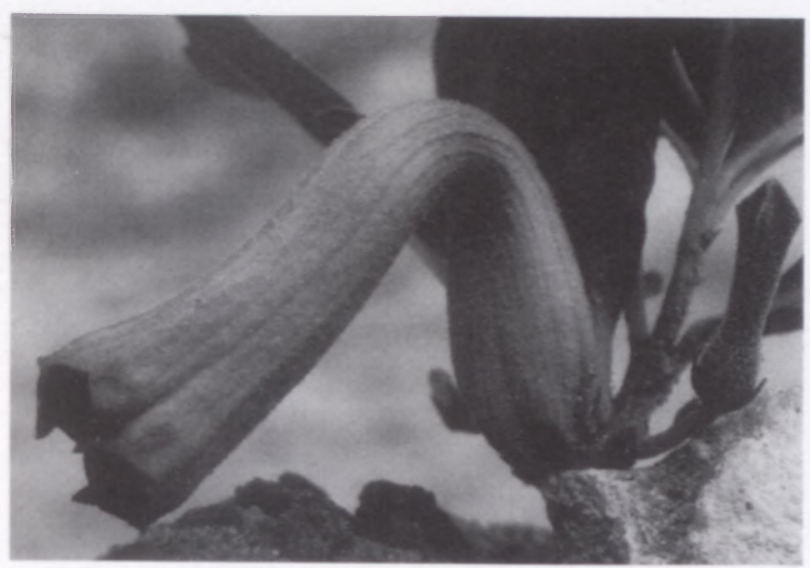

FIGURE 9.-Brachystelma gymnopodum, Bruyns 5512. Plant with broad leaves and very long corolla touching ground at anthesis. 
pedicel glabrous; exterior of corolla glabrous; follicles glabrous. Some of these characters are found in species of Brachystelma but no Brachystelma has all of them.

Another species, Tenaris schultzei (Schltr.) E. Phillips was added in 1941. Here, although the plant often has only a single stem and linear leaves 1-2 mm broad, the stem may branch above and the flowers are not borne on long, slender, unbranched stems. The entire plant is pilose. Schlechter (1914) intended describing this species as a Brachystelma but decided. after a more thorough examination of the gynostegium. that the long. connivent inner corona lobes were more similar to those in Ceropegia than Brachystelma. However, the corolla was entirely different from Ceropegia and hence he placed it in a separate genus Kinepetalum Schltr. Phillips' (1941) placing of this species in Tenaris was not justified by any discussion and, indeed, if it is to be accepted. then it is unclear how Tenaris should be defined. Dyer (1975), partly following Brown (1907-1909), characterised Tenaris by 'Corolla tube almost obsolete, with linear, linear-spathulate or sometimes filiform lobes, slender erect herbs with tubers'. However, "corolla tube almost obsolete" and "slender erect herbs with tubers" would fit many species of Brachystelma and T. schultzei [as illustrated in Bruyns (1984)] would not fit comfortably into "slender erect herbs". Also 'linear' or 'filiform lobes" would fit some species of Brachystelma as well (e.g. B. recuncatum. B. gracile).

Schlechter was in favour of segregating many species from Brachystelma but most of his segregate genera were abandoned by Brown (1902-1904). Bullock (1953) seems to have intended reviving some of these segregates and started moving species to Dichaelia, but this was abandoned by Dyer (1980). If one is to make the treatment of this group consistent with that being applied in the Asclepiadeae, and elsewhere in the Stapelieae. then one will have to examine Bullock's statement (1953: 358) that Brachystelma is unsatisfactorily 'heterogeneous' in some detail. In my opinion Bullock's statement is not true except perhaps in respect of the inclusion within the genus of those species with fusiform roots. These species differ in their vegetative parts and florally quite substantially from the remainder of the genus. Also. Dichaelia. as Bullock envisaged it, is unsatisfactory and it would be unwise to resurrect the genera Siphonostelma Schltr. and Kinepetalum which seem to be superfluous.

Nevertheless there appears to be a case for maintaining Tenaris as distinct from Brachystelma provided it is confined to the seven species of Brown (1902-1904; 19(0)-19(49). Brachystelma christianeae Peckover (1992) also belongs to this genus. Furthermore, it needs to be considered carefully whether Tenaris should be united with the monotypic Macropetalum which also shares most of the above-mentioned characters. There seems to be no justification for placing $T$. schultzei in Tenaris and it should be moved to Brachystelma. This change is effected below.

\subsection{Brachystelma schultzei (Schltr.) Bruvns comb. nov.}

Kinepelulum schultzei Schltr. in Botanische Jahrbücher 51: 150 (1914). Tenaris schultzei (Schltr.) E. Phillips (1941). Lectotype: Namibia. Okakuja, Dinter 2528 (SAM).

To summarise the information above, one may separate the four genera Brachystelma. Ceropegia, Macropetalum and Tenaris as follows:

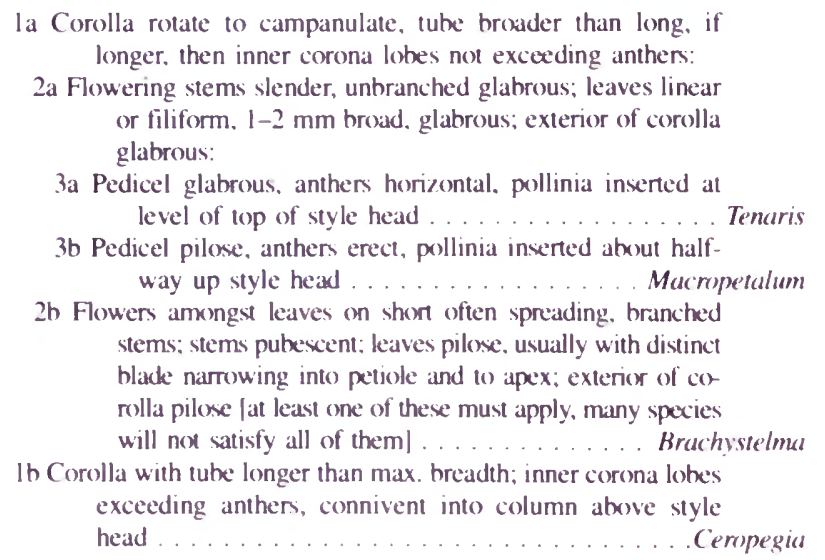

The key to Brachystelma in Namibia in Bruyns (1984) is incomplete, dealing only with the five species discussed there. There are now 11 species recognised from Namibia and it is necessary to construct a key to them. This key is somewhat complicated, using characters of the corona as well as more obvious ones.

\section{Key to Brachystelma spp. in Namibia}

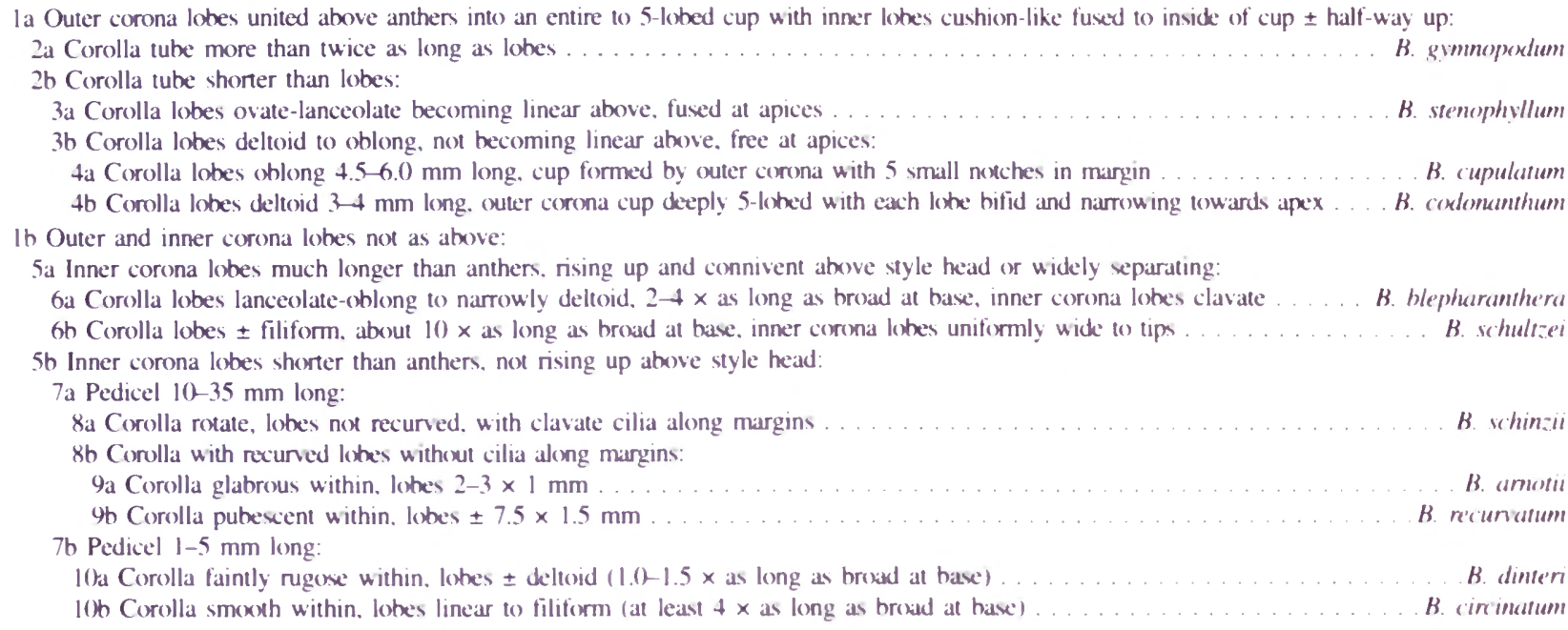




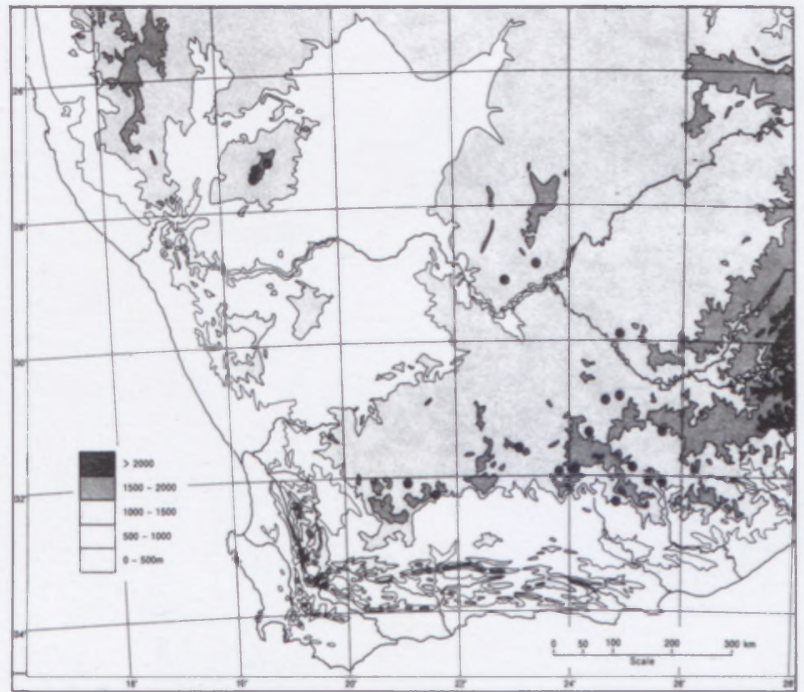

FIGURE 10.-Distribution of Ceropegia filiformis

\section{CEROPEGIA $L$.}

\subsection{Ceropegia filiformis (Burch.) Schltr.}

The collections cited below are the first known from Namibia and extend the known distribution of this species about $450 \mathrm{~km}$ to the west. There are no known localities from the intervening territory between these Namibian gatherings and that of William Burchell, who originally discovered it in 1812 between Kloof and Witwater, southwest of Griquastad in the northern Cape. The distribution map (Figure 10) has been compiled from material seen in BOL, NBG, from PRECIS records, collections (2922 BB, 2824 CD) cited by Wilman (1946) and two collections in cultivation in Cape Town. From the map the extremely wide and scattered range is clear with the records from Namibia providing a remarkable case of vicariance. Most of the other known localities lie on the Great Karoo in the Cape from Richmond eastwards to Colesburg and south to Pearston and Somerset East with further unusual records in the southwest between Sutherland and Fraserburg. There is a single collection from the Orange Free State near Lückhoff. This distribution is unique in the genus (Bruyns 1985).

In January 1989, after good rains had fallen, several colonies of plants were found on the eastern side of the Great Karas Mountains. Plants were scrambling in the open among stones or climbing on Rhigozum trichotomum bushes on flat areas on the summit of mountains. On the western side (seen February 1993) they are also quite plentiful at higher levels and usually found climbing on Rhigozum trichotomum.

Specimens of Ceropegia filiformis are extremely inconspicuous. The plant usually consists of an unbranched, thin (about $1 \mathrm{~mm}$ thick) cylindrical stem (up to $0.8 \mathrm{~m}$ but usually $150-300 \mathrm{~mm}$ long) arising from a dense cluster of thick, spreading, whitish, fusiform roots. The leaves are narrow, linear-lanceolate. On the other hand the flowers, which are 50-60 mm long, are quite striking. Most of the exterior is greyish mottled with purple. The contrast on the lobes of white on the medial keel against the dull purple remainder and striking, narrow, replicate, purpleblack margin makes them easily visible. A peculiar feature of this deeply coloured margin, which has particularly large epidermal cells, is the secretion along its length of regularly spaced droplets of a clear liquid. The function of this liquid remains unknown. The inside of the basal inflation of the corolla is white with longitudinal green stripes on which rows of scattered green papillae are located. These stripes continue up into the constricted part of the tube without the papillae. There are no hairs at all inside the corolla tube (Figure 11).

The outer corona has unusual, thickened, brownish or purple-red apices. The rest of the corona is white to yellow-white, flecked with purple-red spots, quite densely on the inner corona lobes, sparsely on the outer lobes. The raised style-head projecting above the anthers (Figure $11 \mathrm{~L}$ ) is most unusual. This is known in a few Brachystelma species but not in any other Ceropegia.

C. filiformis is unusual among the species with fusiform roots, slender non-succulent stems and leaves in that the stems are cylindrical and not angled. Its affinities among the other southern African species remain unclear.

\section{Specimens examined}

NAMIBIA -2718 (Grünau): Great Karas Mountains, (-BC), \pm 1650 m, Bruyns 5767 (WIND); (-BD), $1600-1700 \mathrm{~m}$, Bruyns 3523 (BOL, WIND); (-DA), $\pm 1600 \mathrm{~m}$, Bruyns 5806 (WIND).

NORTHERN CAPE - 3123 (Victoria West): (-DD), Tyson 410 (BOL); (-CA), Bruyns 4230 (no specimen). 3124 (Hanover): (-AD), Bruyns 3275 (BOL); (-CC), Meve 347 (BOL). 3221 (Merweville): (-AA), Bruyns 4840 (BOL); (-BC), Bruyns 5969 (BOL).

EASTERN CAPE.-3125 (Steynsburg): (-CC), Bruyns 5060 (no specimen). 3224 (Graaff-Reinet): (-BD), Bruyns 1960 (NBG). 3225 (Somerset East): (-AB), Bruyns 1767 (NBG); (-BA), J.R. James (BOL).

\subsection{Ceropegia dinteri Schltr}

Dinter first collected this species around Rehoboth, where it has not been seen again. Several gatherings have been made from west of Outjo to Grootfontein (Bruyns 1984). The four collections listed below extend the known distribution over $400 \mathrm{~km}$ to the north and make it possible that this rare and inconspicuous species occurs in Angola.

Plants were found on dolomite and granite hillsides growing between rocks or in stony bare patches under trees. Tubers were observed from $25-60 \mathrm{~mm}$ in diameter. The stem (1.0-1.5 mm thick) is frail and spindly but reaches a height of over $500 \mathrm{~mm}$ with leaves up to 100 $\mathrm{mm}$ long. If the plant is growing in the open among short grasses, the stem is short-the stem in Figure 12 was about $150 \mathrm{~mm}$ long. Flowers are exceptionally variable with no two the same in size, shape or colouring. The differences between flowers illustrated in Dyer (1983: $t$. $17)$ and the present Figures 12 \& 13C give some idea of this variability.

\section{Specimens examined}

NAMIBIA_-1713 (Swartbooisdrif): (-AC), $1200-1500 \mathrm{~m}$, Bnryns 4092 (BOL); (-DA), 1170 m, Bnuns 4095. 1813 (Opuwo): (-DD), Bniyns 5548 (BOL); south of Kaoko Otavi, 18-02-1993, Bruyns 5557 (K). 


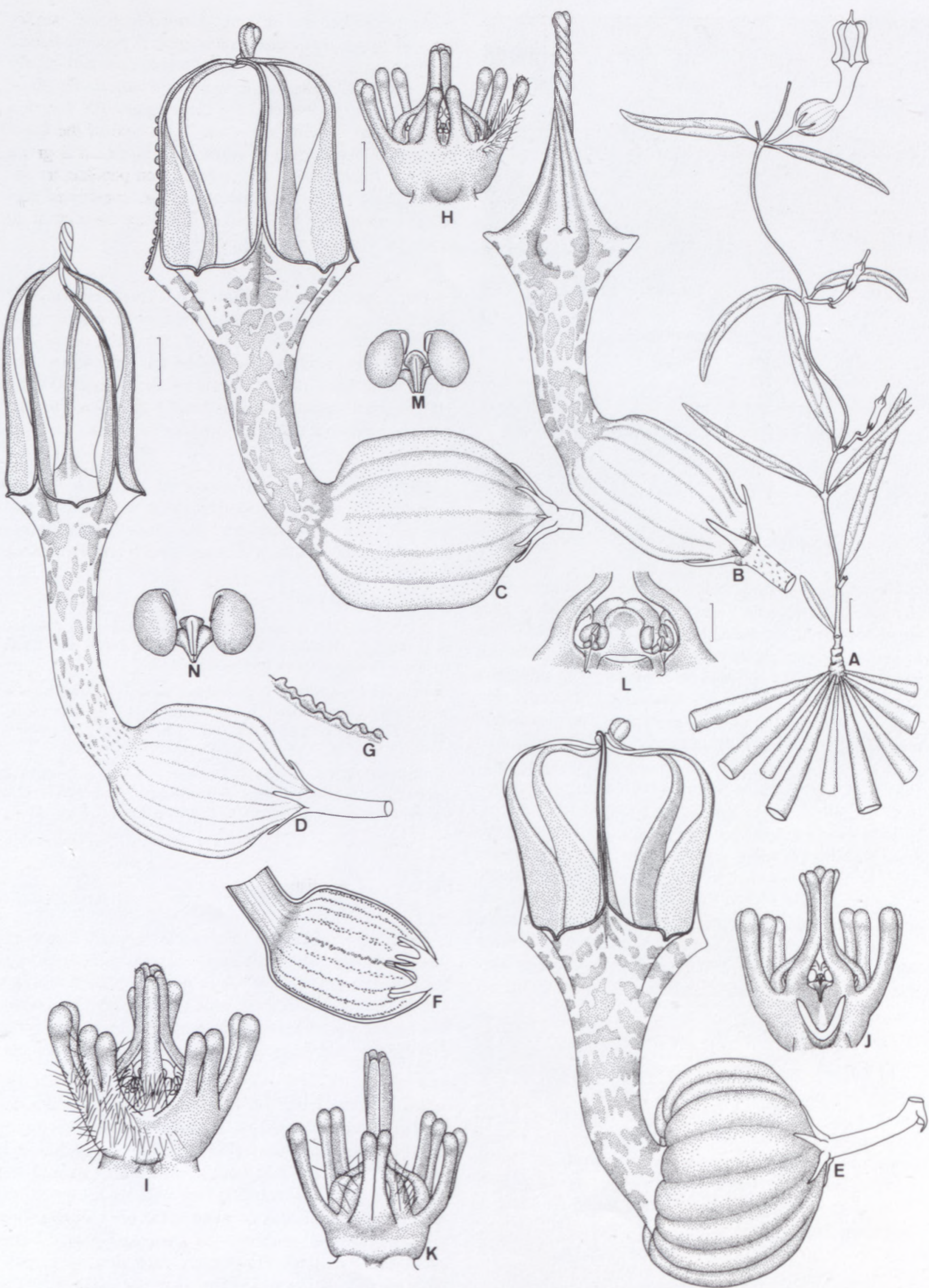

FIGURE 11.-Ceropegia filiformis. A, plant; B, bud; C-E, flower, F, l.s. of inflated base of flower: longitudinal ridges of papillae; G, papillae from within basal inflation of flower. H-L, gynostegium: J, one corona lobe removed; L, top, outer corona and one inner corona lobe removed, anthers and + elongated style-head. M, N, pollinaria. Scale bars: A, 10 mm; B F, 3 mm (at C); G-K, I mm (at H); L, 0.5 mm; M, N, 0.25 mm (at H). A, B, C, I, L, Bruyns 3275; D, K. N, Brunns 3523; E, J, M, Brunns 1960; F, G, H, Meve 347. 


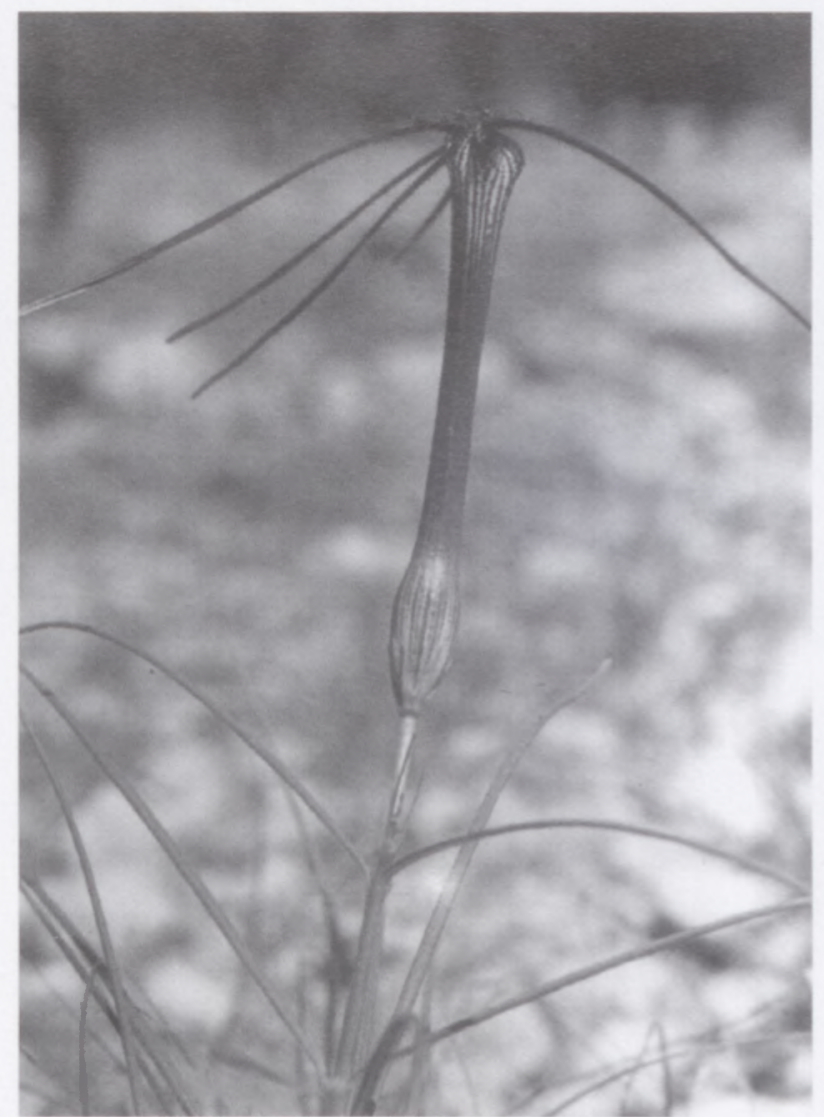

FIGURE 12.-Ceropegia dinteri, Bruyns 5557. Flower: corolla tube 41 $\mathrm{mm}$ long.

\section{GOMPHOCARPUS $R$. $B r$.}

According to Bullock (1952: 406) and Nicholas \& Goyder (1992), the genus Asclepias should be confined to species from the New World since the type species, $A$. syriaca L., is an American species. Most of the larger, shrubby species from Africa placed in Asclepias by Brown should be referred to Gomphocarpus $\mathrm{R}$. Br. The majority of the names have already been transferred to Gomphocarpus and it is only necessary now to decide which species occur in Namibia.

In Kolberg et al. (1992), Asclepias buchenaviana and A. fruticosa appear under Asclepias whereas Gomphocarpus tomentosus is listed under Gomphocarpus. If Bullock's system is to be used then clearly this is inconsistent and all three should appear under Gomphocarpus as in Bullock (1952). Three other species are also known from Namibia and are listed neither in Huber (1967) nor Kolberg et al. (1992).

A key is provided for all the species now known for Namibia and, since the synonymy of some is rather complicated, this is listed and discussed briefly.

Key to Gomphocarpus in Namibia

la Leaves not more than $2 \mathrm{~mm}$ broad, follicles $4-6 \mathrm{~mm}$ broad when mature

G. filiformis

Ib Leaves broader than $4 \mathrm{~mm}$, follicles usually much more than $15 \mathrm{~mm}$ broad when mature: 2a Plant glabrous in all parts, leaves at least $25 \mathrm{~mm}$ broad with rounded lobes clasping stem at base ......G. glaucophyllus

2b Plant pubescent or puberulous at least on young shoots and leaves, leaves less than $20 \mathrm{~mm}$ broad at max., subsessile to shortly petiolate without stem-clasping basal lobes:

3a Leaves oblong-lanceolate to elliptic, usually rounded at base, coriaceous and somewhat rigid .....G. cancellatus

3b Leaves linear or linear-lanceolate, acute, tapering gradually into petiole, thin:

4a Follicle without bristles on exterior, produced into apical beak at least $25 \mathrm{~mm}$ long . . . . . . . . G. rostratus

$4 \mathrm{~b}$ Follicle covered with soft bristles, beak not more than $15 \mathrm{~mm}$ long:

5a Young parts of stem, leaves and inflorescences densely white-tomentose (plant grey-green) . . . . . . .

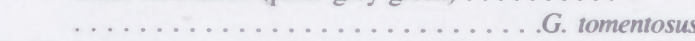

$5 \mathrm{~b}$ Young parts of stem, leaves and inflorescence not densely white-tomentose (plant yellow-green) . . ..................... fruticosus

4.1 Gomphocarpus cancellatus (Burm. f.) Bruyns, comb. nov. Asclepias cancellata Burm. f., Flora Indica: cui accedit series zoophytorum indicorum nec non prodromus florae capensis: 7 (betw. 1 March and 6 Apr. 1768).

\section{A. rotundifolia Miller (1768).}

A. arbonescens L.: 216 (1771). Gomphocarpus arborescens (L.) W.T. Aiton: 79 (1811).

A. pubescens L.: 215 (1771).

Brown (1907-1909) was incorrect in using the name A. rotundifolia Miller as this was published on 16 April 1768, slightly after $A$. cancellata. Several other names exist for this plant, of which only Asclepias arborescens L. has been transferred to Gomphocarpus.

G. cancellatus is common in the southwestern Cape and even occurs in places as a roadside weed. In Namaqualand and the Richtersveld it is rare and there appears to be only a single record of its occurrence in Namibia, some distance north of Rosh Pinah but well within the winter rainfall zone.

\section{Specimen examined}

NAMIBIA.-2716 (Witpütz): (-DA), Bruyns 3927 (BOL).

4.2 Gomphocarpus filiformis (E. Mey.) Dietr., Synopsis plantarum 2: 900 (1839-1852). Lagarinthus filiformis E. Mey.: 203 (1836-1838). Asclepias filiformis (E. Mey.) O. Kunze: 268 (1886) non Jacq. (1760).

Asclepias buchenaviana Schinz: 261 (1888). A. filiformis var. buchenaviana (Schinz) N.E. Br.: 336 (1902-1904).

The name Asclepias buchenaviana has become familiar. The species was first described as Lagarinthus filiformis by Meyer in 1837 but this name cannot be used in Asclepias because of Asclepias filiformis Jacq. (1760), a species from the Caribbean. However, there is no reason for it not to be used in Gomphocarpus.

4.3 Gomphocarpus fruticosus (L) W.T. Aiton, Hortus kewensis (1810-1813).

Asclepias fruticosa L: 216 (1753). 
4.4 Gomphocarpus glaucophyllus Schltr. 19 (1894).

Asclepias glaucophylla (Schltr.) Schltr: 455 (1896).

Rare, only found in the northeastern portion of Namibia.

\section{Specimen examined}

NAMIBIA.-1718 (Nkurenkuru): (-CD), De Winter 3881 (WIND).
4.5 Gomphocarpus rostratus (N.E. Br.) Bullock in Kew Bulletin: 410 (1952).

Asclepias rostrata N.E. Br.: 331 (1902-1904).

A widespread species in tropical Africa known from Kenya, Tanzania (Bullock 1.c.), Angola and Botswana (Brown 1.c.) and from two collections in Namibia.

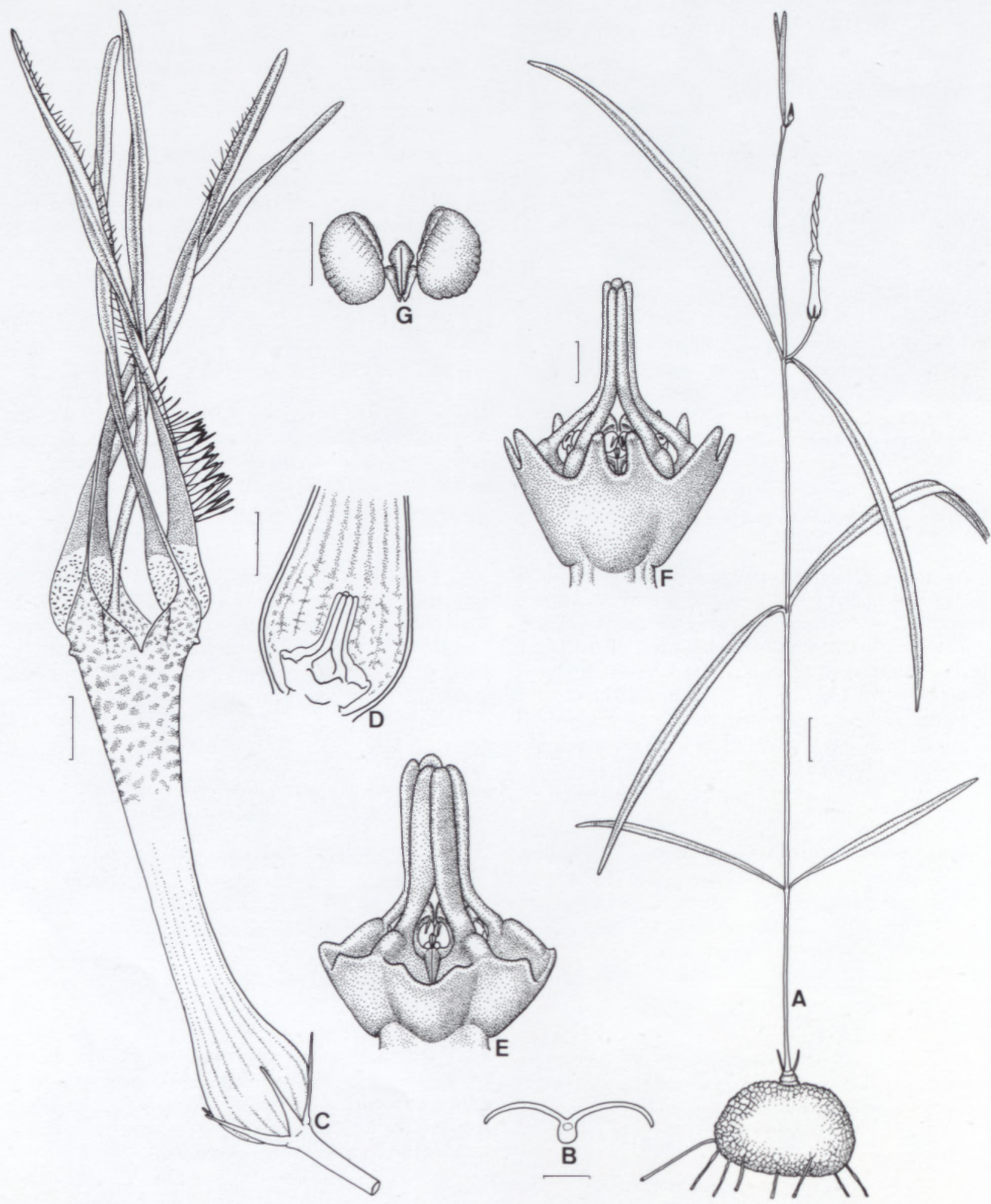

FIGURE 13.-Ceropegia dinteri. A, plant; B, cross-section of leaf taken more or less in middle; C, flower; D, base of corolla dissected; E, F, gynostegium; G, pollinarium. Scale bars: A, $10 \mathrm{~mm}$; B, $1 \mathrm{~mm}$; C, $3 \mathrm{~mm}$; D, $2 \mathrm{~mm}$; E, F, $0.5 \mathrm{~mm}$; G, $0.25 \mathrm{~mm}$. F drawn from Bruyns 2062 , Outjo, remainder from Bruyns 4095. 


\section{Specimens examined}

NAMIBIA.-1719 (Rundu): (-DC), De Winter \& Marais 5037 (WIND). 1724 (Katima Mulilo): (-DD), Killick \& Leistner 3153 (WIND).

4.6 Gomphocarpus tomentosus Burch., Travels 1: 453 (1822). Asclepias burchellii Schltr.: 336 (1895).

Bullock (1952: 406) regarded this taxon as a synonym of $G$. fruticosus but, as Huber (1967) pointed out, two distinct species appear to be involved.

\section{PACHYCARPUS E. Mey.}

Smith (1988) revised the southern African species of Pachycarpus, recognising 24 species for the region. All of them seem to occur only on the eastern side of southern Africa and neither there nor in Huber (1967) are any species mentioned for Namibia. Nevertheless, as early as 1955, B. de Winter gathered a plant clearly identifiable as a Pachycarpus in northern Namibia. Recent collections by B. Strohbach and myself have again brought to light the same taxon.

\subsection{Pachycarpus schweinfurthii (N.E. Br.) Bullock}

According to Bullock (1953), P. schweinfurthii is very widely distributed in tropical Africa from Nigeria and $\mathrm{Su}$ dan southwards to Angola and Zimbabwe. In Namibia it only occurs in the moister northeastern region (Figure 5) and its occurrence in Botswana is also likely.

I have attempted to insert $P$. schweinfurthii into Smith's (1988) key to the southern African species of Pachycarpus (see below) by adding an extra couplet, and a description is also provided. Unfortunately the drawings in Smith's paper are not clear and it is hard to see what the characters used in the key really refer to, especially as there is no explanation of the terminology adopted for the different floral parts. In the specimen here the guide rails (anther wings of Smith) are a little over $3 \mathrm{~mm}$ long. The distance from the edge of the rail to the centre of the flower increases as one goes from the corpusculum towards the base of the flower (clearly seen in Figure 14D) and I assume that this is what Smith means by 'outer margin concave'. I have changed this to 'with concave margin' as there is no 'inner' margin which the use of 'outer' implies.

It may be of use to observe here that the 'corona lobes' referred to above and throughout Smith (1988) are the 'staminal corona' lobes of Kunze (1982) corresponding to the 'inner corona lobes' of the Stapelieae. It seems to be assumed generally that in the species in the AsclepiasGomphocarpus-Pachycarpus-Schizoglossum complex the corona only consists of these five lobes of staminal origin. However, in most species I have looked at, there are five more lobes which are of interstaminal origin (Kunze 1982). Unlike in the Stapelieae (where these 'outer corona lobes' are generally well developed), here they are minute and mostly hidden behind and below the large mouth at

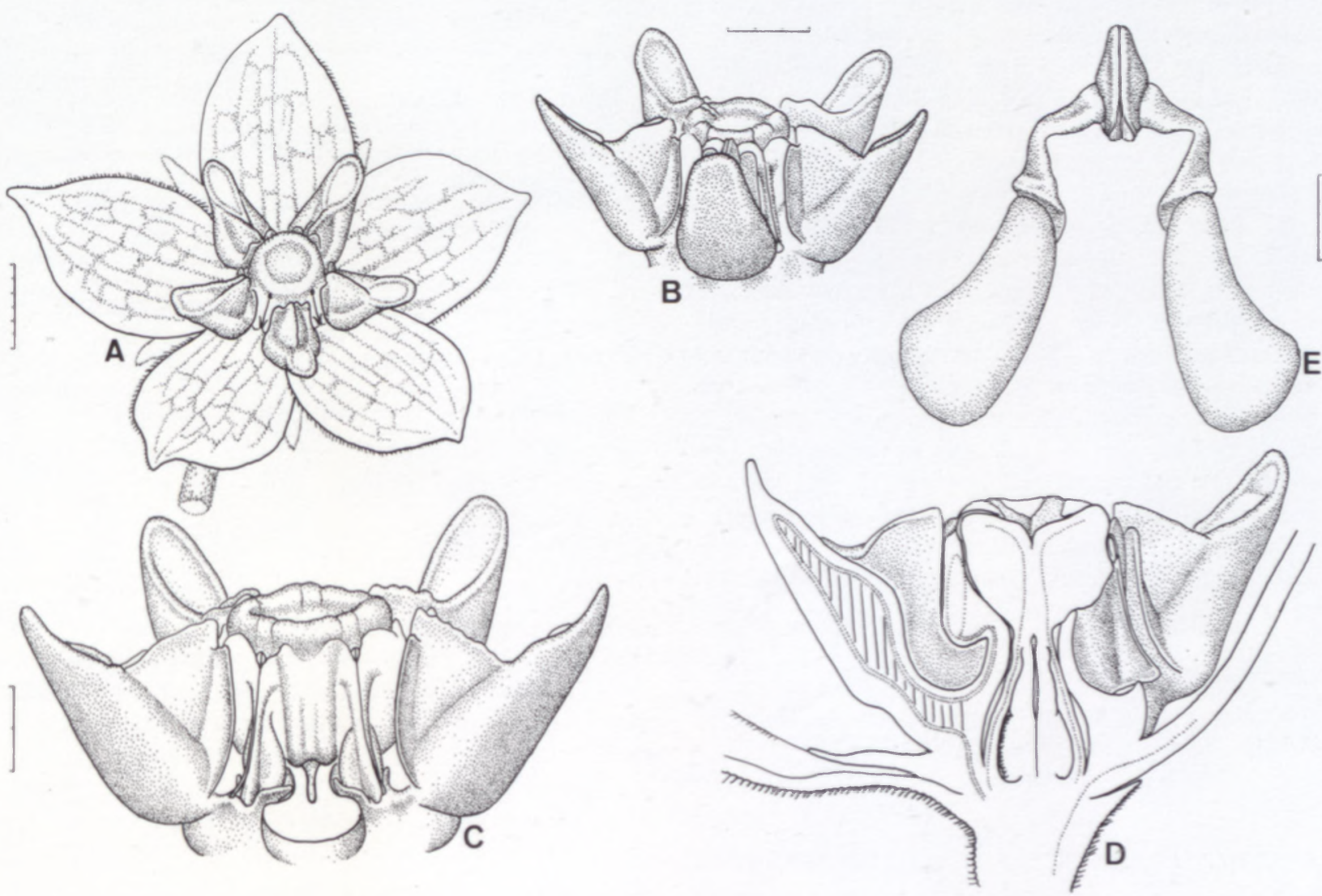

FIGURE 14.-Pachycarpus schweinfurthii, Bruyns 5484. A, flower; B, gynostegium; C, gynostegium with one corona lobe removed; D, half flower; E, pollinarium. Scale bars: A, $6 \mathrm{~mm}$; B, $3 \mathrm{~mm}$; C, D, $2 \mathrm{~mm}$ (at C); E, $0.5 \mathrm{~mm}$. 


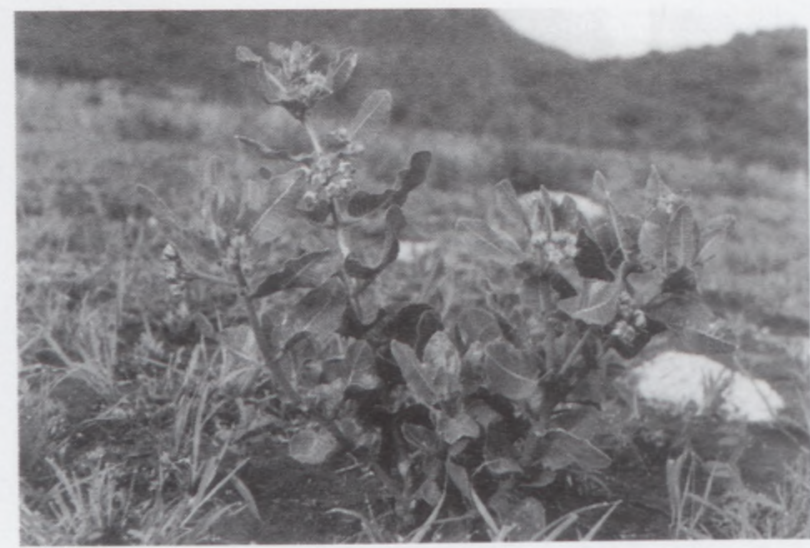

FIGURE 15.-Pachycarpus schweinfurthii, Bruyns 5484, in habitat.

the base of the guide rail so they have probably been missed. They are clearly visible in Figure 14C, each lobe divided into two narrow, widely diverging teeth encircling the base of the guide rail.

\section{Part of key taken from Smith (1988)}

19 a Guide rail (anther wings) $1.3-2.4 \mathrm{~mm}$ long with \pm straight margin . . . . . natalensis

$19 \mathrm{~b}$ Guide rail 3.0-7.2 mm long with concave margin:

$20 \mathrm{a}$ Flower rotate-campanulate, corolla lobes spreading but curved inwards in upper half . . .......P. schweinfurthi 20b Corolla lobes reflexed:

$20 \mathrm{ba}$ Keel of corona lobe taller than broad

$20 \mathrm{bb}$ Keel of corona lobe not taller than broad ... P. appendiculatus

Plant to $450 \mathrm{~mm}$ tall, consisting of 1 -several ascending stems, all parts stiffly pubescent except where indicated otherwise (Figure 15). Stems 3-5 mm thick. Leaf 30-70 × 20-50 $\mathrm{mm}$, ovate to ovate-lanceolate, apex rounded, base truncate to cordate, green with many prominent parallel veins, petiole 4-10 mm long. Peduncle 20-55 mm long, $\pm 2 \mathrm{~mm}$ thick, bearing 4-10 \pm simultaneously opening flowers, bracts narrowly lanceolate, 6-14 $\mathrm{mm}$ long, pedicels $15-18 \mathrm{~mm} \times$ 1.0-1.5 mm thick. Sepals 10-12 × 2-3 mm (at base), widening very slightly above base then lanceolate, pubescent below, glabrous above. Corolla $30-35 \mathrm{~mm}$ diam., rotatecampanulate; lobes $15 \times 9 \mathrm{~mm}$, ovate, finely pubescent outside and on one margin, glabrous within, white suffused with reddish outside, inside white with conspicuous greyish red veining. Gynostegium 14-15 mm across; outer conona lobes minute, bifid and spreading adpressed to base of guide rails; inner corona lobes ascending, $\pm 7 \mathrm{~mm}$ long, exceeding height of style-head, with keel $2 \mathrm{~mm}$ tall, just equalling stylehead, keel and part below it white, part above keel pinkish red.

\section{Specimens examined}

NAMIBIA_-1917 (Tsumeb), Otavi Mountains, (-DB), Bruyns 5484 (BOL, K). 1920 (Tsumkwe): (-BC), Strohbach 1268 (WIND).

\section{SCHIZOGLOSSUM E. Mey. sensu lato in Namibia}

During recent expeditions to the northern parts of $\mathrm{Na}$ mibia several plants belonging to the former genus Schi- zoglossum have been collected. These have proved very difficult to identify to species level and information on these collections is presented here in the hope that they may add to the knowledge of the group. This group was worked on extensively by Kupicha (1984) who, following Bullock (1952), resurrected the genus Aspidoglossum E. Mey. and created a new genus Miraglossum Kupicha as well as concurring with Bullock's resurrection of Stenostelma Schltr. and Glossostelma Schltr. However, she provided no keys to all these genera and various lengthy diagnoses have to be perused to sift out the salient details for identifications.

In Kolberg et al. (1992) various species were left erroneously in Schizoglossum with Kupicha cited as the authority for this. In fact she placed S. baumii Schltr. ex N.E. Br. under Aspidoglossum masaicum (N.E. Br.) Kupicha (not S. bidens subsp. atrorubens (Schltr.) Kupicha) and S. pentheri Schltr. tentatively under Aspidoglossum erubescens (Schltr.) Bullock so that Schizoglossum sensu stricto is not known in Namibia. Nevertheless, I have included it in the key which follows. The differentia that Kupicha (1984) gives for Stenostelma seem to me to have so much overlap with the other genera that I have reverted to the shape of the style-head to separate this genus from the others as Schlechter (1894) originally did: this works for S. capense but may cause problems with the other species tentatively assigned to this genus by Kupicha.

Key to genera of the Schizoglossum complex in Namibia

la Style-head conical, anther appendages much exceeding stylehead connivent in centre and hiding it entirely, caudicles conspicuously angled, broadly attached to corpusculum

\section{Stenostelma}

lb Style-head flat with slight depression in centre, anther appendages adherent to sides of apex and not covering it, caudicles not conspicuously angled with narrow attachment to corpusculum:

2a Inflorescences pedunculate, pollinia medially attached to caudicle with germinating mouth on outer side

Schizoglossum

2b Inflorescences sessile, pollinia subapically attached usually without germinating mouth, if this is present then located at point of attachment of pollinium to caudicle:

3a Corona lobes fleshy, pollinia without germinating mouth Miraglossum

3b Corona lobes thin, pollinia often with germinating mouth Aspidoglossum

\subsection{Aspidoglossum carinatum (Schltr.) Kupicha}

The taxon illustrated in Figure 16 keys out in Huber (1967) as Schizoglossum pentheri. In Kupicha (1984) one arrives at Aspidoglossum carinatum (Schltr.) Kupicha rather than $A$. erubescens which is where she tentatively placed $S$. pentheri in synonymy. The pollinium lacks the conspicuous germinating zone supposedly typical of $A$. erubescens and so we are unlikely to be dealing with that species.

According to Kupicha (1984: 640), A. carinatum occurs in the eastern Cape Province and Natal. The present. rather exceptional extension of its distribution into north- 
ern Namibia stretches credibility somewhat. In addition, the corona does not correspond very exactly with that of A. carinatum: the ventral appendage of the corona is slender and much exceeds the apical process (not broadly triangular). However, there appears to be nowhere else to place this collection and since the taxonomy of this whole group remains such a mess, I would prefer to avoid describing new taxa which might further confound the situation.

It should be observed that the stem here is uniformly finely pubescent all round and the leaves are pubescent on the ventral surface and glabrous on the dorsal except for the pubescent midrib (Figure 16F). Unless damaged, the plant always consists of a simple, slender, erect stem up to $300 \mathrm{~mm}$ tall with narrow leaves and many small clusters of nearly sessile flowers. There is a small, neat, carrot-like tuber just beneath the surface of the soil (one excavated was $\pm 60 \mathrm{~mm}$ long and $10 \mathrm{~mm}$ broad at apex).

\section{Specimen examined} (BOL).

NAMIBIA.-1917 (Tsumeb): Otavi Mountains, (-DB), Bruyns 5488

6.2 Schizoglossum saccatum Bruyns, sp. nov., a ceteris speciebus pilis longis densis in lobis corollae et lobis coronae crassioribus processa apicale horizontale breve discedit. Typus: Namibia, 1813 (Opuwo), south of
Kaoko Otavi, (-DD), 1400 m, Bruyns 5558 (BOL, holo.; $\mathrm{K}$, WIND, iso.).

Plant much branched at ground level from an underground rootstock, with milky latex. Stems 70-200 $\times$ 1.5-2.0 mm, ascending, hairy all round, internodes 7-25 $\mathrm{mm}$ long. Leaves $20-70 \times 2.5-4.0 \mathrm{~mm}$, narrowly linear, sessile, ventral surface pilose, dorsal glabrous except on midrib, margins recurved, acute at apex and at base. Flowers in fascicles mostly of 4 arising alongside all except the basal nodes; peduncle 7-20 $\times \pm 1 \mathrm{~mm}$, pilose along one side only, with several filiform bracts up to $3 \mathrm{~mm}$ long at apex; pedicel 7-9 $\mathrm{mm}$ long, about $0.5 \mathrm{~mm}$ thick, pilose. Sepals dorsally pilose, ventral surface glabrous, 4-5 $\times 1 \mathrm{~mm}$ (at base), lanceolate, usually recurved towards apex, green. Corolla divided right to base; lobes $6.0 \times 2.5 \mathrm{~mm}$ (at base), ovate-lanceolate, ascendingspreading with recurved margins and apex, dorsal surface glabrous, ventral surface convex and densely white-pilose especially towards apex with hairs up to $1.5 \mathrm{~mm}$ long, green with faint longitudinal purplish stripes. Gynostegium $2.0 \times 5.5 \mathrm{~mm}$, glabrous, white except for purplish pink dorsal apex; outer corona lobes minute, truncate-emarginate, beneath guide rails; inner lobes massive, inflated, \pm ovoid when viewed from above with small apical process projecting horizontally onto anther appendage and broad rounded dorsal process. Fruit and seed not seen. Figure 17.

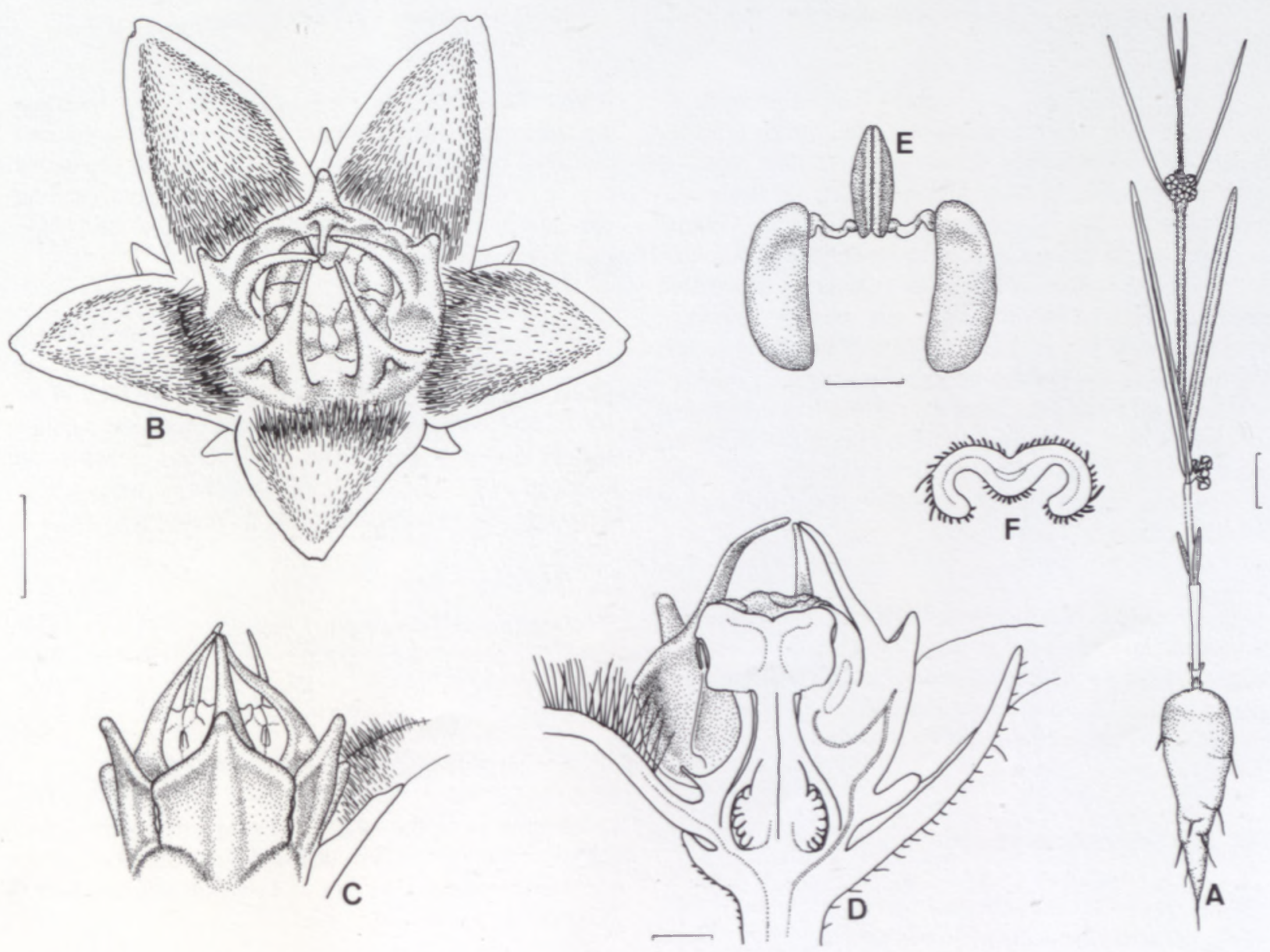

FIGURE 16.-Aspidoglossum carinatum, Bruyns 5488. A, plant, much reduced in length (up to 450 mm tall); B, flower; C, gynostegium; D, half flower; E, pollinarium; F, cross-section of leaf taken near middle showing distribution of thickened hairs. Scale bars: A, 10 mm; B, C. F, 1 $\mathrm{mm}$ (at B); D, $0.5 \mathrm{~mm}$; E, $0.25 \mathrm{~mm}$. 


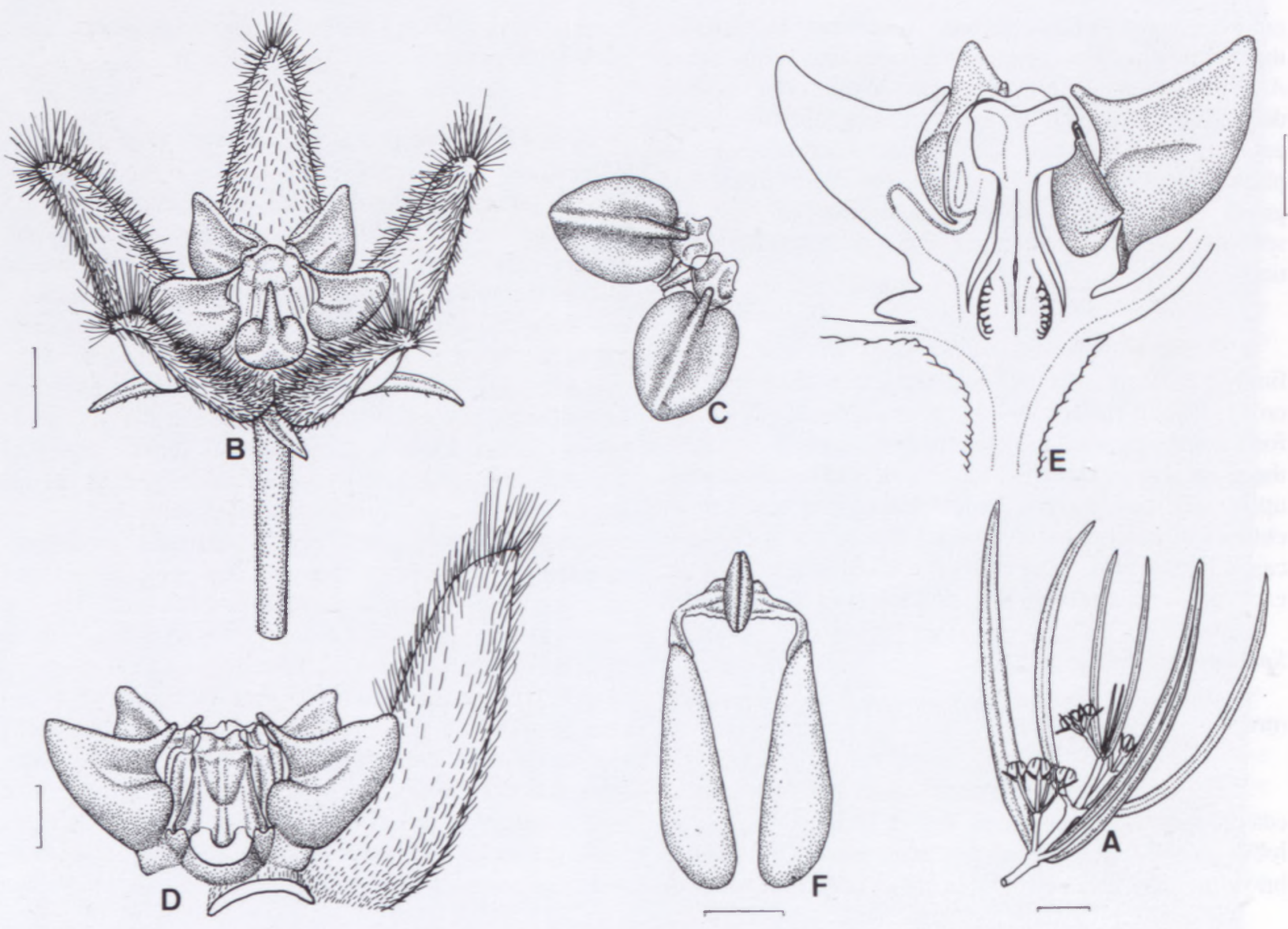

FIGURE 17.-Schizoglossum saccatum, Bruyns 5558. A, portion of plant; B, flower; C, face view of part of corona; D, gynostegium with one corona lobe removed; E, half flower; F, pollinarium. Scale bars: A, 10 mm; B, 2 mm; C, D, $1 \mathrm{~mm}$ (at D); E, $1 \mathrm{~mm}$; F, $0.25 \mathrm{~mm}$.

This species is only provisionally placed under Schizoglossum with which it shares the pedunculate inflorescence but, if Kupicha's (1984) sense of the genus is applied, little else. In Miraglossum, where the fleshy corona lobes and lack of germinating mouth on the pollinia suggest it might belong, it would be a very odd bedfellow with the other species of this small, compactly distributed genus: as Kupicha (in litt.) points out, most of them have whorled leaves in the flowering part of the stem, sessile inflorescences and pollinia attached to the caudicle somewhat on their inner side rather than apically as in this new species. It also seems that the fleshiness of the corona lobes exceeds anything known in Miraglossum. D. Goyder at Kew has tried to match it with existing material or existing genera without success.

Plants were common among limestone chunks in a flat Sesamothamnus-dominated area, growing with a small spiny Euphorbia and many other succulents. They are generally small and inconspicuous and, once the grass begins to grow, are probably difficult to find.

\subsection{Stenostelma capense Schltr.}

This species seems to be widespread but relatively uncommon in northern Namibia. Schlechter (1894) based Stenostelma on the conical shape of the style-head. From the half flowers shown here (compare Figure $18 \mathrm{H}$ with Figure 1D) it can be seen that the style-head is indeed differently shaped to that typical amongst the genera As- clepias, Gomphocarpus, Pachycarpus and Schizoglossum. The anther appendages are also much more conspicuous. Instead of being adpressed to the edge of the pentagonal style-head they here only touch the edge, rise up and are connivent in the centre, in so doing hiding the entire stylehead from view.

In the material illustrated here the stems are pilose in a longitudinal band on one side (the side changing after each node) and are not pilose all round as given by Huber (1967). On the other hand the corolla lobes are papillate all over the inner surface and not glabrous as Schlechter described them. The very tiny outer corona lobes consist of a single, erect tooth beneath the guide rail (Figure 18G).

\section{Specimens examined}

NAMIBIA.-1918 (Grootfontein): Gobis Water, (-AC), Bruyns 5499 (BOL). 1920 (Tsumkwe): $15 \mathrm{~km}$ southeast of Tsumkwe, (-DA), Bruyns 5834 (BOL).

\section{Stigmatorhynchus hereroensis Schltr.}

The genera of the Marsdenieae are so poorly known that every attempt should be made to obtain and publish information on them so that an eventual re-assessment of the tribe is possible.

$S$. hereroensis is common and fairly widespread in the northern portion of Namibia usually growing in areas with much surface limestone. The distribution (Figure 19, 

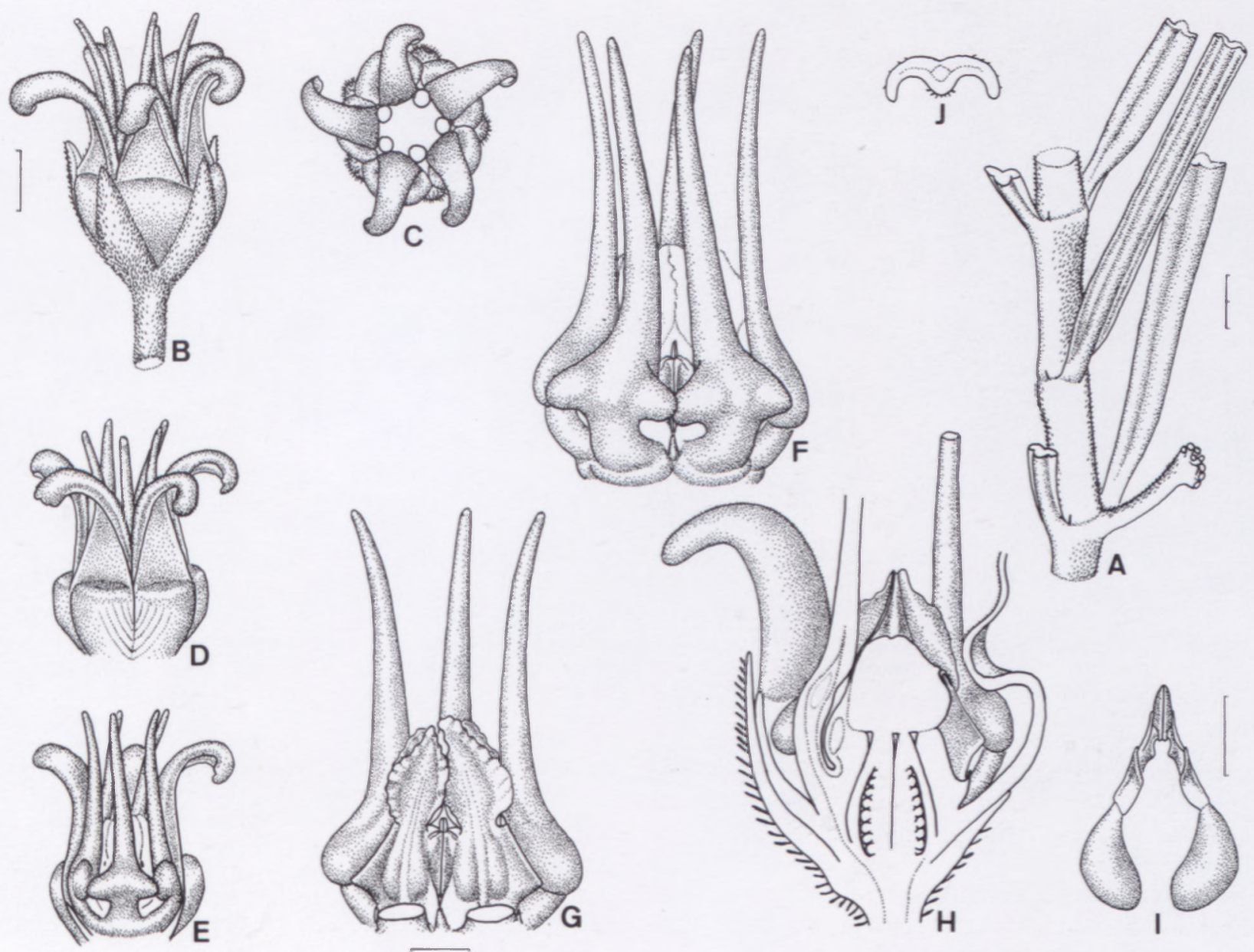

FIGURE 18.-Stenostelma capense, Bruyns 5834. A, part of plant: stem virtually glabrous in patch below insertion of each petiole, peduncle only hairy on upper side. Flowers produced in dense, simultaneously opening clusters on several such peduncles towards apex of stem; B, C, flower; D, flower with sepals removed; E, flower with two corolla lobes excised; F, gynostegium; G, gynostegium with two corona lobes removed; $\mathrm{H}$, half flower (small oval area demarked inside cut corona lobe is hollow); I, pollinarium; J, cross-section of leaf, taken near middle. Scale bars: A, 2 mm; B-E, J, 1 mm (at B); F-H, $0.5 \mathrm{~mm}$ (at G); I, $0.25 \mathrm{~mm}$.

drawn up from material in WIND and BOL) seems to be bounded to the north and east by regions covered with deep Kalahari sand but it remains possible that it extends into Angola and Botswana. Plants often grow in the open but may also be found growing inside other bushes. They are usually heavily grazed.

$S$. hereroensis is a shrub-forming species. Plants usually form a rigid, round bushlet up to about $300 \mathrm{~mm}$ tall but, if sheltered, may reach $1 \mathrm{~m}$ in height, although they never show any tendency to climb. The grey, woody stems contain a milky latex.

Plants bear small white flowers in nearly sessile, simultaneously opening clusters along the stems. Within each flower is a dense beard of whitish hairs, beginning on the lobes, extending into the tube and blocking the throat of the tube. Peculiar to this species (to the genus?) is the very long, cylindrical style-head which protrudes slightly from the tube, and the pair of ovules in each carpel. One of these ovules seems to abort as each pod contains only a single, quite large seed. The pods may be paired or solitary and when paired are divergent from one another at about $120^{\circ}$. The pollinia are very small and attached by long, slender caudicles to the small corpusculum (Figure 20).
Schlechter (1914) placed three species in Stigmatorhynchus, of which the other two, S. umbelliferus (K. Schum.) Schltr. and S. stelostigma (K. Schum.) Schltr. (from Tanzania and Somalia respectively) are unknown

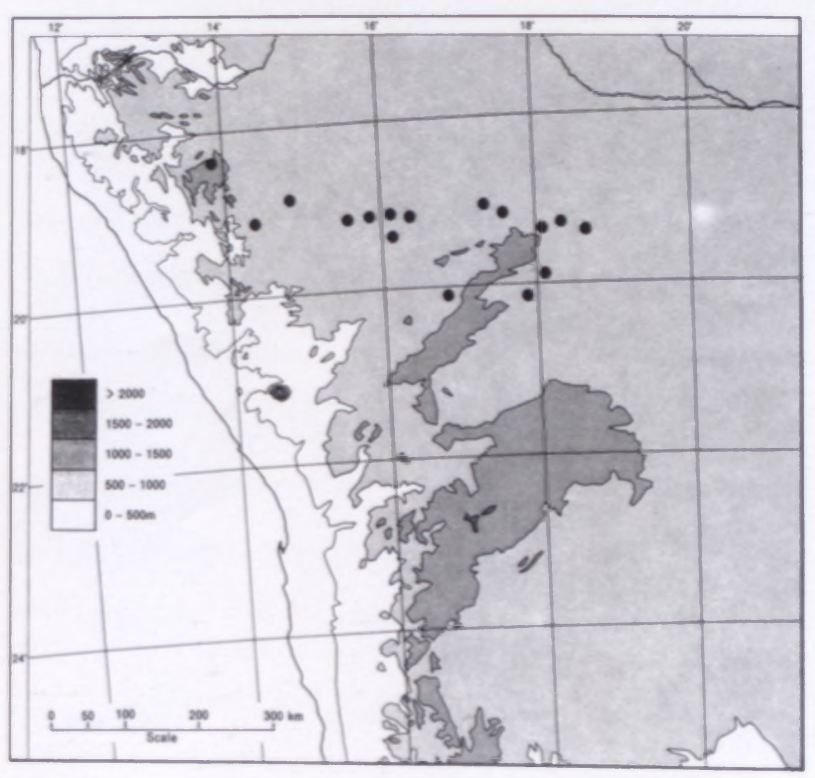

FIGURE 19.-Distribution of Stigmatorhynchus hereroensis in $\mathrm{Na}$ mibia (from records in WIND, BOL). 

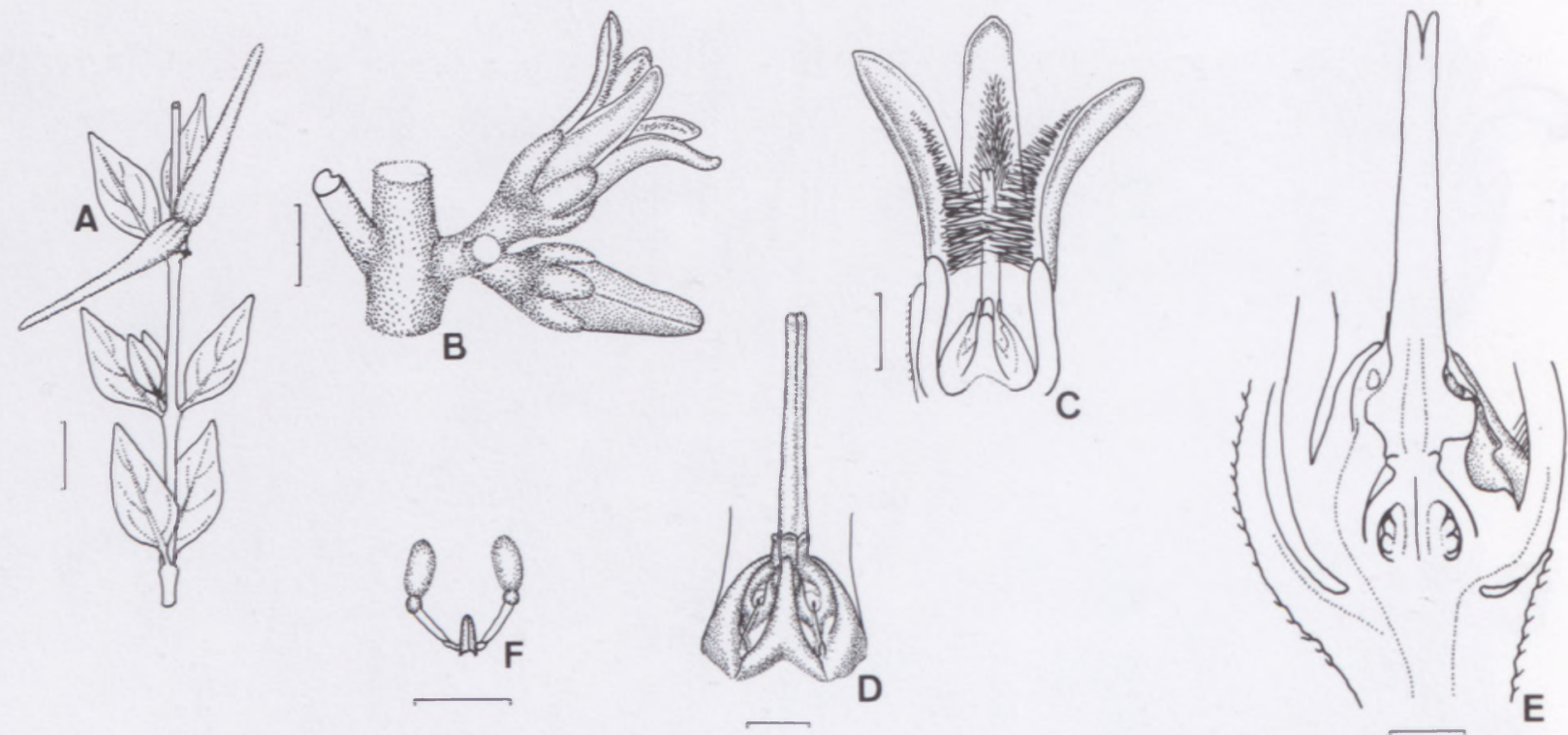

FIGURE 20.-Stigmatorhynchus hereroensis, Bruyns 5833. A, portion of plant with paired follicles; B, flower; C, dissected flower; D, gynostegium; E, half flower, each carpel has two ovules; F, pollinarium with caudicles stretched out. Scale bars: A, $10 \mathrm{~mm} ; \mathrm{B}, 2 \mathrm{~mm}$; C, $1 \mathrm{~mm}$; D, 0.5 $\mathrm{mm} ; \mathrm{E}, 0.5 \mathrm{~mm} ; \mathrm{F}, 0.25 \mathrm{~mm}$

to me. Bullock (1954) transferred S. stelostigma back to Marsdenia R. Br. so that, at present, Stigmatorhynchus contains only two species. It should be noted that Schlechter's illustration (1914) is not very accurate: the pollinaria are very different to what he has shown and the style head maintains a roughly equal diameter right to the apex, where it may sometimes be bifid.

\section{ACKNOWLEDGEMENTS}

I wish to thank A. Nicholas and D.J. Goyder for useful information on members of the Asclepiadeae, where my knowledge is patchy. The Curators of WIND and PRE are thanked for the loan of material.

\section{REFERENCES}

AITON, W.T. 1810-1813. Hortus kewensis, edn 2. London.

BROWN, N.E. 1902-1904. Asclepiadaceae. Flora of tropical Africa 4, 1 : 231-503.

BROWN, N.E. 1907-1909. Asclepiadaceae. Flora capensis 4, 1: 518-1036.

BRUYNS, P.V. 1984. Cemopegia, Brachystelma and Tenaris in South West Africa Dinteria 17: 3-80.

BRUYNS, P.V. 1985. Notes on Ceropegias of the Cape Province. Bradleya 3: 1-47.

BRUYNS, P.V. 1988. A revision of the genus Echidnopsis Hook. f. Bradleya 6: 1-48.

BRUYNS P.V. 1993. A revision of Hoodia and Lavrania. Botanische Jahrbücher 115: 145-270.

BRUYNS, P.V. \& FORSTER, P.I. 1989. Ceropegia cumingiana Decne. Austrobaileya 3: 7-11.

BULLOCK, A.A. 1952. Notes on African Asclepiadaceae I. Kew Bulletin 1952: $405-426$

BULLOCK, A.A. 1953. Notes on African Asclepiadaceae III. Kew Bulletin 1953: 329-362.

BURMAN, N.L. 1768. Flora indica: cui accedit series zoophytorum indiconum nec non prodromus florae capensis: 7. Amsterdam, Leiden.

DIETRICH, D.N.F. 1839-1852. Synopsis plantarum. Voigt, Weimar.

DYER, R.A. 1975. The genera of southern African flowering plants 1. Government Printer, Pretoria.

DYER, R.A. 1980. Asclepiadaceae. Flora of southem Africa 27, 4. Government Printer, Pretoria.
DYER, R.A. 1983. Ceropegia, Brachystelma and Riocreuxia in southerm Africa. Balkema, Rotterdam.

FORSTER, P.I. 1988. Studies in the Australasian Asclepiadaceae. I. Brachystelma Sims in Australia. Nuytsia 6: 285-294.

HUBER, H.E. 1957. Revision der Gattung Ceropegia. Memorias da Sociedade Broteriana 12

HUBER, H.E. 1967. Asclepiadaceae. Prodromus einer Flora von Südwestafrika 114

JACQUIN, N.J. 1760. Enumeratio systematica plantarum. Haak, Leiden. KOLBERG, H., GIESS, W., MÜLLER, M.A.N. \& STROHBACH, B. 1992. List of Namibian plant species. Dinteria 22.

KUNZE, H. 1982. Morphogenese und Synorganisation des Bestäubungsapparates einiger Asclepiadaceen. Beiträge zur Biologie der Pflanzen 56: 133-170.

KUNZE, O. 1886. Jahrbuch des Königlichen Botanischen Gartens Berlin 4: 268.

KUPICHA, F.K.A. 1984. Studies on African Asclepiadaceae. Kew Bulletin 38: $599-672$.

LINNAEUS, C. 1753. Species plantarum. Stockholm.

LINNAEUS, C. 1771. Mantissa plantarum. Stockholm.

MEYER, E.H.F. 1836-1838. Commentariorum de plantis Africae australis: 203. Leipzig.

MILLER, P. 1768. The gandener's dictionary. London.

MÜLLER, M.A.N. 1984. Brachvstelma blepharanthera Huber-rediscovered after 70 years. Dinteria 17: 81 .

NICHOLAS, A. 1982. Taxonomic studies in Asclepias with particular reference to the narnow-leaved species in southem Africa. M. Sc. Thesis, University of Natal, Pietermaritzburg.

NICHOLAS, A. \& GOYDER, D. 1992. Aspidonepsis, a new southern African genus. Bothalia 22: 23-35.

PECKOVER, R. 1992. A new species of Brachystelma from Natal. Aloe 29: $56,57$.

PHILLIPS, E. P. 1941. Newly described species and new combinations. Bothalia 4: 41

SCHINZ, H. 1888. Verhandlungen des Botanischen Vereins Brandenburg 30 .

SCHLECHTER, R. 1894. Beiträge zur Kenntnis südafrikanischer Asclepiadaceen. Botanische Jahrbücher 18 Beiblatt 45: 19.

SCHLECHTER, R. 1895. Asclepiadaceae elliotianae. Journal of Botany 33: 333-339.

SCHLECHTER, R. 1896. Asclepiadaceae.In H. Schinz, Beiträge zur Kenntnis der Afrikanischen Flora 4. Bulletin de l'Herbier Boissier 4: 450.

SCHLECHTER, R. 1914. Asclepiadaceae africanae. Botanische Jahrbücher 51: 129-155.

SMITH, D.M.N. 1988. A revision of the genus Pachycarpus in southem Africa. South African Journal of Botany 54: 399-439.

WILMAN, M. 1946. Preliminary checklist of the flowering plants and ferns of Griqualand West. Deighton Bell. Cambridge. 